\title{
Article \\ Causality between Energy Consumption and Economic Growth in the Presence of Growth Volatility: Multi-Country Evidence
}

\author{
Gulasekaran Rajaguru ${ }^{1, *(D)}$ and Safdar Ullah Khan ${ }^{1,2}$ \\ 1 Bond Business School, Bond University, Gold Coast, QLD 4229, Australia; skhan@bond.edu.au \\ 2 Economy, Planning and Development, Gold Coast, QLD 9726, Australia \\ * Correspondence: rgulasek@bond.edu.au; Tel.: +61-755-952-049
}

check for

updates

Citation: Rajaguru, Gulasekaran, and Safdar Ullah Khan. 2021.

Causality between Energy

Consumption and Economic Growth in the Presence of Growth Volatility: Multi-Country Evidence. Journal of Risk and Financial Management 14: 471 https://doi.org/10.3390/jrfm14100471

Academic Editor: Peter

J. Stauvermann

Received: 17 September 2021

Accepted: 1 October 2021

Published: 7 October 2021

Publisher's Note: MDPI stays neutral with regard to jurisdictional claims in published maps and institutional affiliations.

Copyright: (c) 2021 by the authors. Licensee MDPI, Basel, Switzerland. This article is an open access article distributed under the terms and conditions of the Creative Commons Attribution (CC BY) license (https:// creativecommons.org/licenses/by/ $4.0 /)$

\begin{abstract}
Falling energy intensity (increasing efficiency) is believed to be a result of more efficient production methods that have evolved over time, indicating overall sustainability in the production process. The objective of this study is to investigate the diminishing trend of energy intensity and the related volatilities in growth of energy consumption and income growth through the energygrowth nexus. The country specific long-run and short-run causal relationships among real energy consumption per capita, real GDP per capita, and the volatilities of growth in income and the growth in energy consumption are established using the method proposed by Yamamoto-Kurozumi within a cointegration framework in 48 countries. The overall findings suggest that energy intensity is falling, in conjunction with the existing evidence on the energy-growth nexus in most of the countries studied; hence, implicitly this confirms sustainability. The results based on volatility analysis show a significant decrease in energy use in response to increasing income growth volatility. The negative effects of income growth volatility on energy consumption are usually countered through compensation measures, with subsidies provided to households and producers in order to smooth the energy consumption behaviours in those economies.
\end{abstract}

Keywords: keyword causality; energy consumption; economic growth; volatility; YamamotoKurozumi framework

\section{Introduction}

The main purpose of this paper, by controlling for volatility in income growth and energy use, is to shed light on the global trend of falling energy intensity using the energygrowth nexus. Falling energy intensity (increasing efficiency) is believed to be a result of more efficient production methods that have evolved over time, indicating overall sustainability in the production process. Furthermore, energy intensity is also considered an expression of the price/cost of transferring energy into GDP (Menegaki and Tsani 2018). Hence, a reduced amount of energy usage with a greater GDP has been shown to be a great success. Many studies have examined all the possible interactions between energy and GDP growth for many countries in the form of country-specific time series analyses or in a panel data framework. They have observed four types of relationship-GDP growth causing energy consumption, energy consumption causing GDP growth, a feedback relationship, or no causality. However, the aspect of energy intensity has been explicitly ignored in the energy-growth literature. Furthermore, there is no explanation available on the negative causal effects of income on energy consumption, indirectly indicating that falling energy intensity may provide a pathway towards total sustainability. The falling energy intensity has been explained to some extent by Agovino et al. (2018) and Shahbaz et al. (2018) for European countries and for the top 10 energy consumers, respectively, through the negative causal relationship of GDP to primary energy consumption. Nepal et al. (2014) found that market liberalisation, the financial sector, and most infrastructure industries drove energy intensity to fall. In contrast, Salim et al. (2019) found that increasing population and non-renewable energy usage increased energy intensity, according to evidence from 
Asian countries. This study moves the discussion forward by investigating energy intensity through the energy-growth nexus, using a set containing many countries.

Figure 1 presents the falling trend in energy intensity across regions over more than one and a half decades. The overall energy intensity decreased by an average of $1.58 \%$ per annum from 1990 to 2016, with the highest decline of $2.75 \%$ in the BRICS countries and the lowest decline of $1.46 \%$ in the OECD countries. These diminishing trends in energy intensity show that energy consumption has declined relative to per-capita production levels-potentially, this may lower the adverse environmental impacts of energy use and production costs, hence achieving sustainability. According to the International Energy Agency (IEA), although the global energy consumption has declined by 12 percent, the energy efficiency has increased by $13 \%$. Along similar lines, Rühl et al. (2012) have discovered that aspects including economic systems, resource endowments, and technology have supported the lowering of energy intensity through supplementing conversions and end-use efficiency. This can be inferred as an unconventional revolution in terms of humans' environmental impacts.

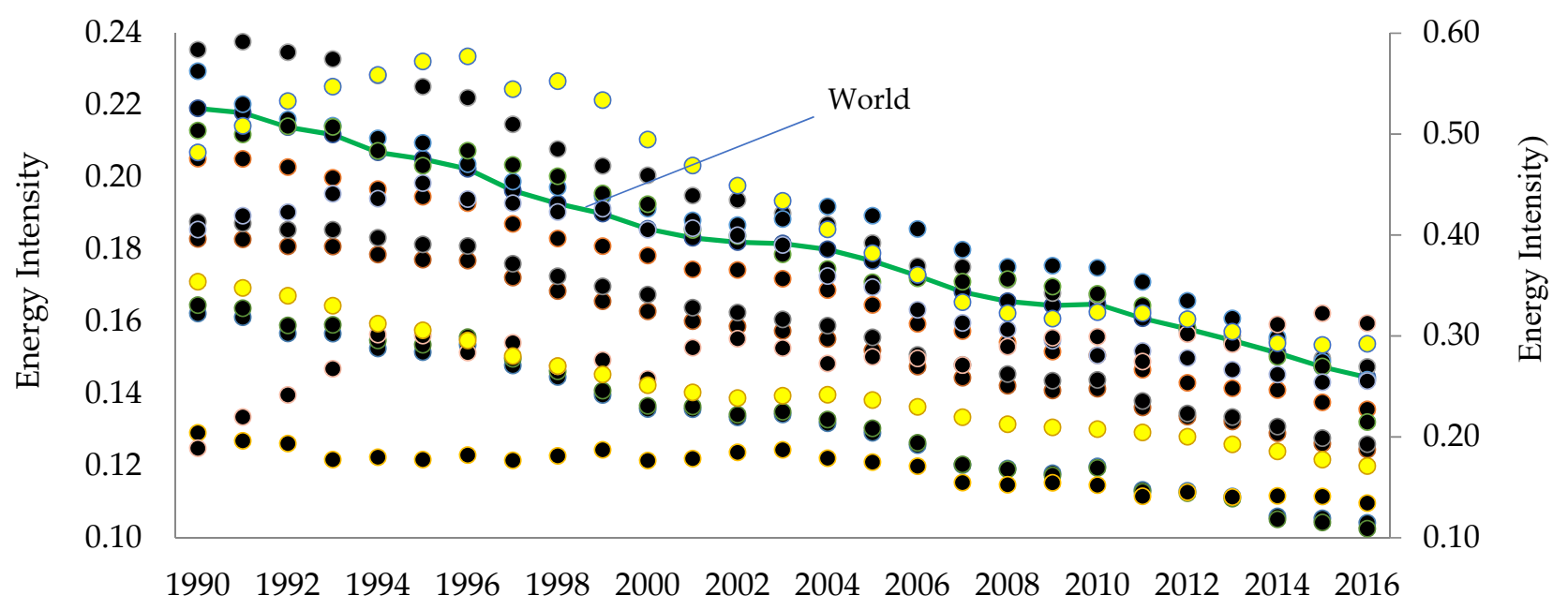

Figure 1. Trends in energy intensity (1990-2016). Notes: Energy intensity at constant purchasing power parities (koe/\$2005). This figure includes trends from all regions, including Africa, America, Asia, BRICS and CIS countries, Europe, the European Union, the G7, Latin America, the Middle East, North America, OECD countries, and the Pacific. All regions, except CIS and BRICS countries, are plotted against the primary axis. CIS and BRICS countries are plotted against the secondary axis. These two regions are plotted in yellow.

Figure 2 shows the trends in energy intensity (panel a) and real GDP per capita (panel b) for the sample of 48 countries (covering both energy exporting and importing countries, as in Jalil (2014)) included in our empirical study. Historically, the energy intensity presents wider fluctuations-although it consistently fell during the last one and a half decades - matched with irregular swings in per-capita income. Therefore, volatility analysis becomes relevant in the energy-growth nexus, a fact which has been grossly ignored in the previous literature on this topic. The causal relationship between economic growth and income volatility has been reported by several conspicuous studies (Aizenman and Marion 1993; Bernanke 1983; Pindyck 1991; Hnatkovska and Loayza 2005; Black 1987). However, there is no study available on energy-income volatility, according to the best of the author's knowledge. 


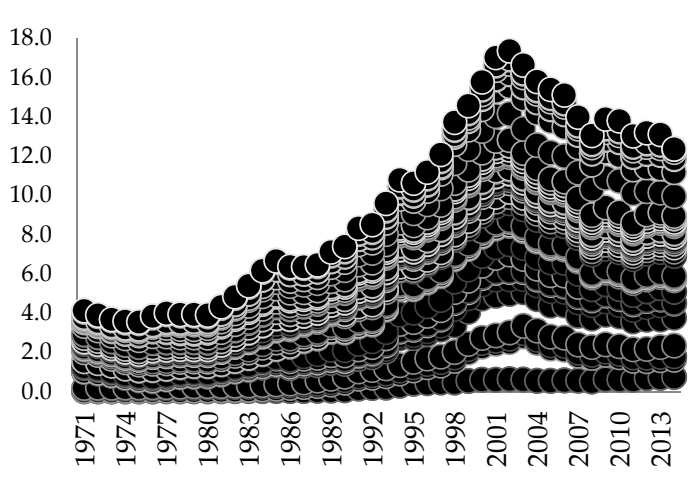

(a)

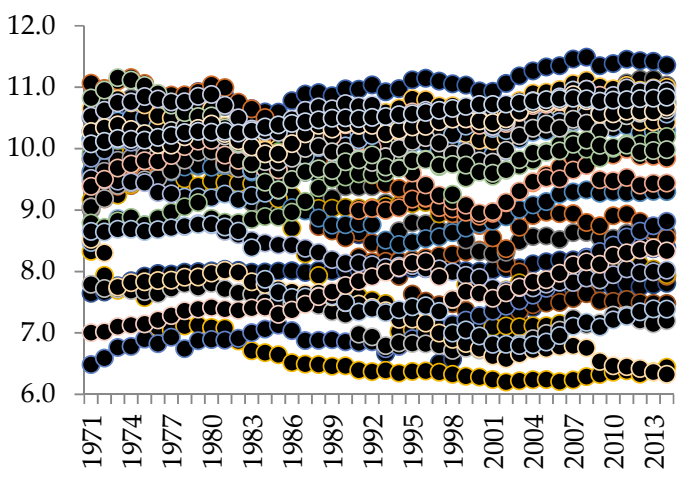

(b)

Figure 2. (a) Log(energy intensity); (b) $\log ($ per-capita GDP). Note: The trends in energy intensity and real GDP per capita for the sample of 48 countries used in this study.

Tiba and Omri (2017) provide a comprehensive literature survey on energy growth nexus covering a range of empirical studies which are conveniently classified into countryspecific, multi-country, and panel data analysis. Most of the literature investigates direction of causality between energy consumption and GDP growth, which remains a matter of concern among policy makers. Moreover, the available literature lacks sufficient consensus, hence it invites all possible corners of criticism. The current study takes a different approach and makes energy intensity the foundation of analysis, which has been grossly ignored in the previous literature on this topic. Furthermore, this study incorporates the uncertainty (volatility) in income growth on the energy-growth nexus and offers a novel contribution to the literature. The current study contributes to the energy-growth debate in many ways. First, we describe the recent shifts in the conventional energy-growth nexus in terms of diminishing energy intensity. We estimate the coefficient of income on energy intensity within the energy-growth framework, which explains the variations in energy intensity. Therefore, we examine the following four hypotheses within the energy-growth nexus in conjunction with the notion of falling energy intensity:

Hypothesis 1 (H1). Growth hypothesis—a unidirectional causality from energy consumption to economic growth.

Hypothesis 2 (H2). Conservation hypothesis - a unidirectional causality from economic growth to energy consumption.

Hypothesis 3 (H3). Feedback hypothesis— the feedback causal relationship between energy consumption and income (often referred as feedback hypothesis in the literature). and

Hypothesis 4 (H4). Neutrality hypothesis—no causality between income and energy consumption (known as neutrality hypothesis in the literature).

In H1, the primary energy consumption helps to maintain economic growth and the energy conservation policies may be jeopardised. Furthermore, the energy efficiency would be compromised along with environmental costs. The above might also be reflected through increasing trends of the energy intensity. However, with significant falling energy intensity, the energy conservation process does not necessarily halt growth. In other words, growth remains sustainable with maintaining the given levels of energy consumption. This also refers to increasing energy efficiency, which in turn contributes towards stronger growth.

In H2, energy consumption follows economic growth. This hypothesis allows us to compare the evidence in the light of currently falling energy intensity. $\mathrm{H} 3$ highlights a 
two-way causality between energy and growth. This helps to understand the multiplier effect of primary energy consumption in terms of increasing economic growth, has some obvious environmental implications-this is beyond the scope of this study. In H4, in terms of energy-intensity, energy efficiency will not be related to growth; therefore, energy intensity is not significantly falling.

Second, we analyse income growth and energy consumption growth volatilities using exponential generalised conditional heteroscedasticity (EGARCH) models for each country and incorporate them into the standard energy-growth nexus. The connections between the volatility of income growth and energy consumption will have useful policy implications. Hacker et al. (2014) argued that income volatility causes economic insecurity. Economic insecurity may have grave implications in regard to meeting intensity-based targets of greenhouse gas emissions and sustainable economic growth. Carmona et al. (2017) observed a pro-cyclical movement in energy consumption and economic growth cycles in the USA. Gately and Huntington (2002) explored the asymmetric effects of changes in income and price on energy demand. Liddle and Sadorsky (2020) analysed the effect of asymmetric changes in income and energy prices on energy demand for the panel of 91 OECD and non-OECD countries in a non-linear cointegration framework. Their study did not find any evidence of asymmetry due to income. Their model captures the asymmetry through increases or decreases in GDP rather than the income growth volatility. Liddle et al. (2020) analysed the time-varying income and price elasticities for energy demand using a dynamic model framework. Owyang et al. (2008) discovered in the USA that high energy consumption decreases macroeconomic volatility. Rashid and Kocaaslan (2013) empirically examined the connections between income and energy volatilities in the United Kingdom They found a significant relationship between energy consumption and GDP volatilities. Furthermore, they observed that volatility in energy consumption determines volatility in income-particularly, regimes with higher volatility present a stronger relationship between energy and income volatilities. Though Rashid and Kocaaslan explore the causal relationship between these volatilities, they failed to analyse the causal link extending from the volatilities of economic growth and energy consumption growth to the economic growth and energy consumption growth and vice versa. Therefore, we investigate whether unexpected variations (volatility) in energy consumption growth are related to economic growth and energy consumption growth and vice versa. We examine the following two hypotheses within the energy growth nexus:

Hypothesis 5 (H5). There exists a positive feedback relationship between the income growth volatility and the energy consumption volatility.

Hypothesis 6 (H6). Uncertainties in income growth (income growth volatility) will have adverse effect on energy consumption.

In summary, we establish the causal relationship between (i) energy consumption and income (transmission between the means); (ii) volatilities of economic growth and income growth (transmission between the variances); and (iii) energy consumption and income and the volatilities of energy consumption and economic growth (transmission between the means and the variances).

Third, we establish the long-run and short-run causality relationships among real energy consumption per capita, real GDP per capita, and the volatilities of growth in income and the growth in energy consumption through the Yamamoto and Kurozumi (2006) technique within a cointegration framework. Since the results based on earlier literature are sensitive to the effects of sampling frequency, the sign rule by Rajaguru and Abeysinghe (2008) is used to determine the non-spurious causal inferences. Fourth, we estimate the country-wise results for all 48 countries. This helps us to understand the correct relationship between energy and growth by maintaining the respective drivers of energy and environment-related effects for each country. The model can also be estimated using appropriate panel data methods. However, as we shall see later, the estimated elasticities 
are not invariant in relation to individual countries. The results could be misleading if we assume homogeneity across the countries or regions if the model is estimated in a panel framework. Furthermore, it has been reported in Menegaki and Tsani (2018) that country-specific estimates are mostly different from the results of pooled (panel) regression models, such as those discussed in the main study by Apergis and Payne (2012). They have noted that almost $73 \%$ of the individual studies on the clean energy-growth nexus is different from their principal study.

The novel contribution to the literature is the implementation of the volatility in the energy-growth nexus to explain the falling trend in the energy intensity. At the same time, the paper also contributes to the energy-growth literature by establishing the non-spurious long-run causal inferences using a sign rule, along with the Yamamoto and Kurozumi technique, which is invariant to sampling frequency.

The rest of the paper is organised as follows. The review of literature review is presented in Section 2. Data and methods are discussed in Section 3. The results and discussion are presented in Section 4. Finally, Section 5 presents concluding remarks, along with important policy inputs.

\section{Literature Review}

Tiba and Omri (2017) offered a systematic review of more than 250 studies on the energy-growth nexus, covering the period from 1978 to 2014. They included studies dealing with country-specific, multi-country, and panel data analysis. Many studies have used panel data analysis to analyse the causal inferences between income and energy consumption (for example, Apergis and Payne 2012; Belke et al. 2011; Eggoh et al. 2011; Yildirim and Aslan 2012; Hossein et al. 2012; Damette and Seghir 2013; Mohammadi and Parvaresh 2014; Śmiech and Papież 2014; Larissa et al. 2020; Batrancea et al. 2020; Batrancea 2021). Although a panel data study gains from a statistical power viewpoint, it fails to capture the country-specific characteristics in many instances (Menegaki and Tsani 2018). On the other hand, country-specific studies offer a range of conclusions, subject to the methods used and the availability of data. On occasion, we have found studies with different inferences for the same country. Such differences are largely attributed to methods of analysis and the availability of time-series data. Extensive research has shown that the various sampling frequencies due to temporal aggregation and systematic sampling may distort the causal inferences and exogeneity of results (Rajaguru et al. 2018). For example, in the case of China, some have observed evidence in favour of the causality from economic growth to energy consumption (also known as conservation hypothesis in the literature) (Chang 2010; Wang et al. 2011a), others have witnessed the causality from energy consumption to economic growth (commonly known as growth hypothesis in the literature) (Wang et al. 2011b; Zhang 2011; Zhixin and Xin 2011). Similarly, many studies have estimated contradictory results from United States (Kraft and Kraft 1978; Akarca and Long 1980; Yu and Hwang 1984; Abosedra and Baghestani 1989; Yu and Jin 1992; Stern 1993; Cheng 1995; Stern 2000; Soytas et al. 2007; Ewing et al. 2007; Payne 2009; Bowden and Payne 2009; Fallahi 2011), India (Cheng 1999; Paul and Bhattacharya 2004), Malaysia (Ang 2008; Tang 2009), New Zealand (Fatai et al. 2004; Bartleet and Gounder 2010) and Pakistan (Aqeel and Butt 2001; Jamil and Ahmad 2010; Shahbaz et al. 2012). To overcome the spurious results due to sampling frequencies, the sign rule by Rajaguru and Abeysinghe (2008) is used to determine the non-spurious causal inferences between the variables of interest.

\section{Data and Methods}

As in Jalil (2014), we also use a sample of 48 countries. We use the World Development Indicators (2017) as the primary source of data information. According to the World Development Indicators, energy consumption refers to the use of primary energy before transformation to other end-use fuels, which is equal to indigenous production plus imports and stock changes, minus exports and fuels supplied to ships and aircraft engaged 
in international transport. Real GDP per capita (RGDPPC) in 2011 constant US dollars is used as a measure of income. All variables are converted into real constant prices per capita.

We use the exponential autoregressive conditional heteroskedasticity (EGARCH) model for income growth and energy consumption growth to generate the volatility measures. The EGARCH model ensures that the variances of income growth and energy consumption growth are non-negative.

The unit root properties of real GDP per capita, energy consumption per capita, income growth volatility, and energy consumption growth volatility are examined by applying the traditional unit root tests, such as the augmented Dickey-Fuller $(A D F)$, Phillips-Perron $(P P)$, and Kwiatkowski-Phillips-Schmidt-Shin (KPSS) unit root tests. However, a stationary variable can be misinterpreted as I(1) in the presence of structural breaks. For this purpose, we use the break-point unit root test developed by Carrion-i-Silvestre et al. (2009). The unit root test results are not reported in the Appendix A (Tables A1-A4). The results show that the real GDP per capita (RGDPPC) and energy consumptions per capita $(E C P C)$ are $I(1)$ at the five-percent level of significance. The results also indicate that the volatility measures of both income growth (INVOL) and energy consumption growth (EVOL) are stationary, $\mathrm{I}(0)$. In addition, these volatility measures will not exhibit a long-run relationship between them and others.

Since RGDPPC and ECPC are I(1), the existence of long-run relationships between $R G D P P C, E C P C, I N V O L$, and EVOL are examined through $\lambda_{\text {trace }}$ and $\lambda_{\text {max }}$ cointegration tests. When we include the two stationary variables (INVOL and $E V O L)$ in the cointegration test, we would expect at least two cointegrating vectors. We would expect the number of cointegrating vectors to be exactly three to establish the long-run relationship between RGDPPC and ECPC in the presence of INVOL and EVOL.

The vector autoregression $(V A R)$ model to conduct the cointegration test can be written as:

$$
\left(\begin{array}{c}
\Delta R G D P C_{t} \\
\triangle E C P C_{t} \\
I N V O L_{t} \\
E V O L_{t}
\end{array}\right)=\mu+\Pi z_{t-1}+\sum_{i=1}^{p-1} \Gamma_{i}\left(\begin{array}{c}
\Delta R G D P C_{t-i} \\
\Delta E C P C_{t-i} \\
I N V O L_{t-i} \\
E V O L_{t-i}
\end{array}\right)+\left(\begin{array}{c}
\varepsilon_{1 t} \\
\varepsilon_{2 t} \\
\varepsilon_{3 t} \\
\varepsilon_{4 t}
\end{array}\right)
$$

where $\mu$ is a vector of constants and $\varepsilon_{t}$ has a covariance matrix $\Sigma$. The long-run $4 \times 4$ matrix is $\Pi=\alpha \beta$ and it determines how many independent linear combinations of the elements of $z_{t}=\left(R G D P P C_{t}, E C P C_{t}, I N V O L_{t}, E V O L_{t}\right)$ are stationary. Here, $\alpha$ and $\beta$ are $n \times r$ matrices of rank $r$. To establish the long-run relationship in the presence of two stationary variables, we expect that $r=3$. In such cases, it has the following representation with the error correction (EC) terms:

$$
\begin{gathered}
e_{1 t}=\beta^{\prime} z_{t}=\ln \left(E C P P C_{t}\right)-\beta \ln \left(R G D P P C_{t}\right) \\
e_{2 t}=I N V O L_{t} \text { and } e_{3 t}=E V O L_{t} \\
\Delta \ln \left(R G D P P C_{t}\right)=\mu_{1}+\gamma_{11} e_{1 t-1}+\gamma_{12} e_{2 t-1}+\gamma_{13} e_{3 t-1}+\sum_{i=1}^{p-1} \delta_{11, i} \Delta \ln \left(R G D P P C_{t-i}\right)+ \\
\sum_{i=1}^{p-1} \delta_{12, i} \Delta \ln \left(E C P C_{t-i}\right)+\sum_{i=2}^{p-1} \delta_{13, i} I N V O L_{t-i}+\sum_{i=2}^{p-1} \delta_{14, i} E V O L_{t-i}+\varepsilon_{1 t} \\
\Delta \ln \left(E C P C_{t}\right)=\mu_{2}+\gamma_{21} e_{1 t-1}+\gamma_{22} e_{2 t-1}+\gamma_{23} e_{3 t-1}+\sum_{i=1}^{p-1} \delta_{21, i} \Delta \ln \left(R G D P P C_{t-i}\right)+ \\
\sum_{i=1}^{p-1} \delta_{22, i} \Delta \ln \left(E C P C_{t-i}\right)+\sum_{i=2}^{p-1} \delta_{23, i} I N V O L_{t-i}+\sum_{i=2}^{p-1} \delta_{24, i} E V O L_{t-i}+\varepsilon_{2 t} \\
I N V O L_{t}=\mu_{3}+\gamma_{32} e_{2 t-1}+\gamma_{33} e_{3 t-1}+\sum_{i=1}^{p} \delta_{31, i} \Delta \ln \left(R G D P P C_{t-i}\right)+ \\
p-1 \\
\sum_{i=1}^{p-1} \delta_{32, i} \Delta \ln \left(E C P C_{t-i}\right)+\sum_{i=2}^{p-1} \delta_{33, i} I N V O L_{t-i}+\sum_{i=2} \delta_{34, i} E V O L_{t-i}+\varepsilon_{3 t}
\end{gathered}
$$




$$
\begin{aligned}
& E V O L_{t}=\mu_{4}+\gamma_{42} e_{2 t-1}+\gamma_{33} e_{3 t-1}+\sum_{i=1}^{p-1} \delta_{41, i} \Delta \ln \left(\text { RGDPPC }_{t-i}\right)+ \\
& \sum_{i=1}^{p-1} \delta_{42, i} \Delta \ln \left(E C P C_{t-i}\right)+\sum_{i=2}^{p-1} \delta_{43, i} I N V O L_{t-i}+\sum_{i=2}^{p-1} \delta_{44, i} E V O L_{t-i}+\varepsilon_{4 t}
\end{aligned}
$$

The parameter $\gamma_{\mathrm{i} 1}$ denotes the speed of the adjustment parameter for the $i$-th equation. Each equation in the system described above can also be viewed as an autoregressive distributed lag (ARDL) model.

The long-run and short-run Granger causality between the variables of interest are examined through the Yamamoto and Kurozumi tests. (see Appendix B for the methodological note). The technical econometrics components are available in the Supplementary Materials. Furthermore, we also incorporate the sign-rule to non-spurious long-run causal relationships which are invariant to sampling frequencies. The sign rule demonstrates that the established long-run Granger causality is non-spurious if the sign of the error correction coefficient, $\gamma_{i}$, is opposite to that of the sign of $\beta_{i}$ in the cointegrating vector. On the other hand, the short-run Granger causality will be based on testing the restrictions on $\delta_{i j}$ in the short-run Equation (3a-d). For example, the short-run Granger causality from growth in income to growth in energy consumption is examined by testing the null hypothesis that $\delta_{21, i}=0$, for all $i$. Furthermore, the sign of the short-run Granger causality from income growth to energy consumption growth is determined by $\sum_{i=1}^{p-1} \delta_{21, i}$. Similarly, the short-run Granger causality from income growth volatility to energy consumption growth is determined by testing the null hypothesis that $\gamma_{22}=0$ and $\delta_{23, i}=0$, for all $i$. Correspondingly, the sign is determined by $\gamma_{22}+\sum_{i=2}^{p-1} \delta_{23, i}$. All estimation and testing except the long-run Granger causality testing using Yamamoto and Kurozumi testing are carried out in Eviews 11. The Yamamoto and Kurozumi testing long-run Granger causality testing is implemented in Gauss 18.

\section{Results and Discussion}

\subsection{Descriptive Evidence}

The energy-growth nexus is complex in many dimensions of the relationship. Although we observed that the income per capita has increased for all countries, Figure 3a shows that the per-capita energy consumption has increased in some countries and decreased in other countries. In particular, we observed a positive relationship between the real GDP per capita and per-capita energy consumption in countries with a relatively lower energy consumption level. On the other hand, countries with a higher energy consumption level tend to display a negative relationship between these two variables. More interestingly, we observed that the energy-intensity is falling in both groups of countries, motivating us to estimate the correct magnitude of the relationship between per-capita energy use and economic growth. Furthermore, Figure 3b depicts the contemporaneous negative relationship between the energy intensity and income per capita across all countries. However, the direction of the contemporaneous (long-run) relationship is not apparent from these descriptive measures. This postulates the basis of our further analysis on the energy-growth nexus through the lens of long-run analysis and the variety of the short-run analyses.

The uncertainty (volatility) in income growth was computed through the EGARCH model for all countries. Figure 4 depicts the relationship between income growth volatility and the growth in energy consumption. We observed that the uncertainty in income growth (higher volatility) reduces the energy consumption. All of the above provide important insights into the energy-growth nexus, which is further explored in the following sections. 


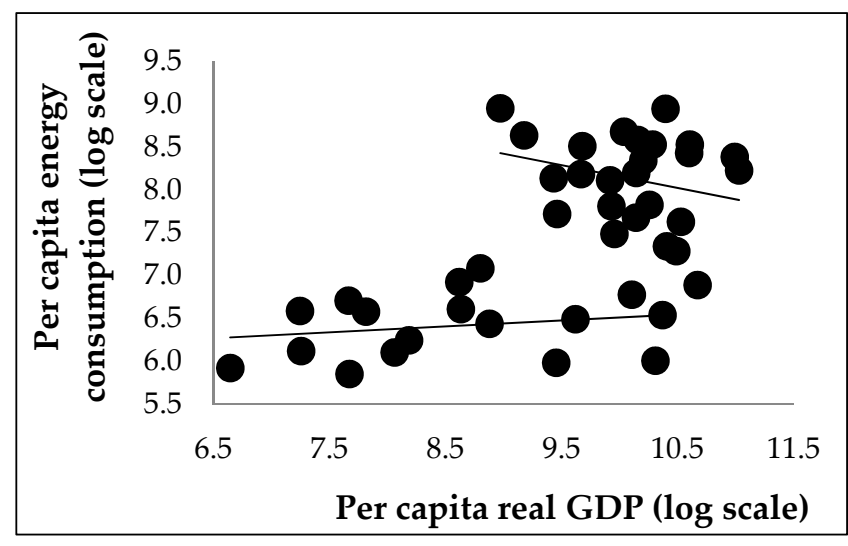

(a)

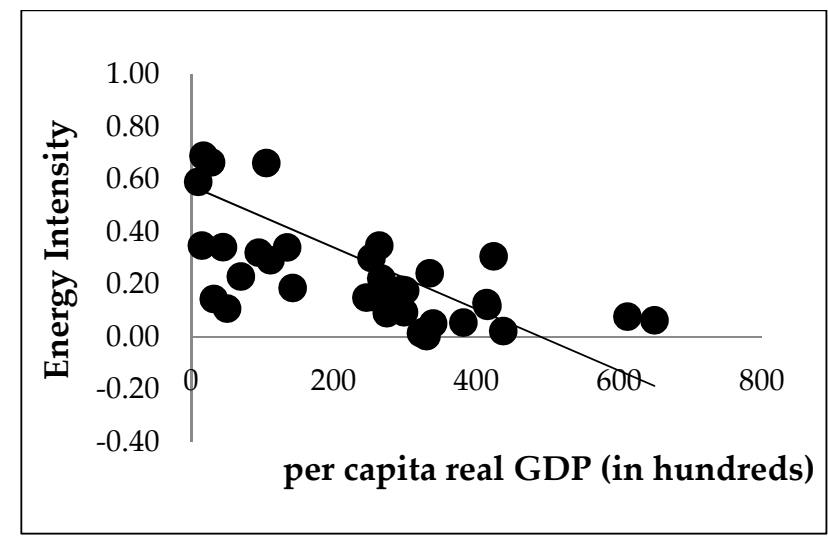

(b)

Figure 3. (a) Real GDP per capita and energy consumption per capita; (b) income and energy intensity (period averages for 1970-2016).

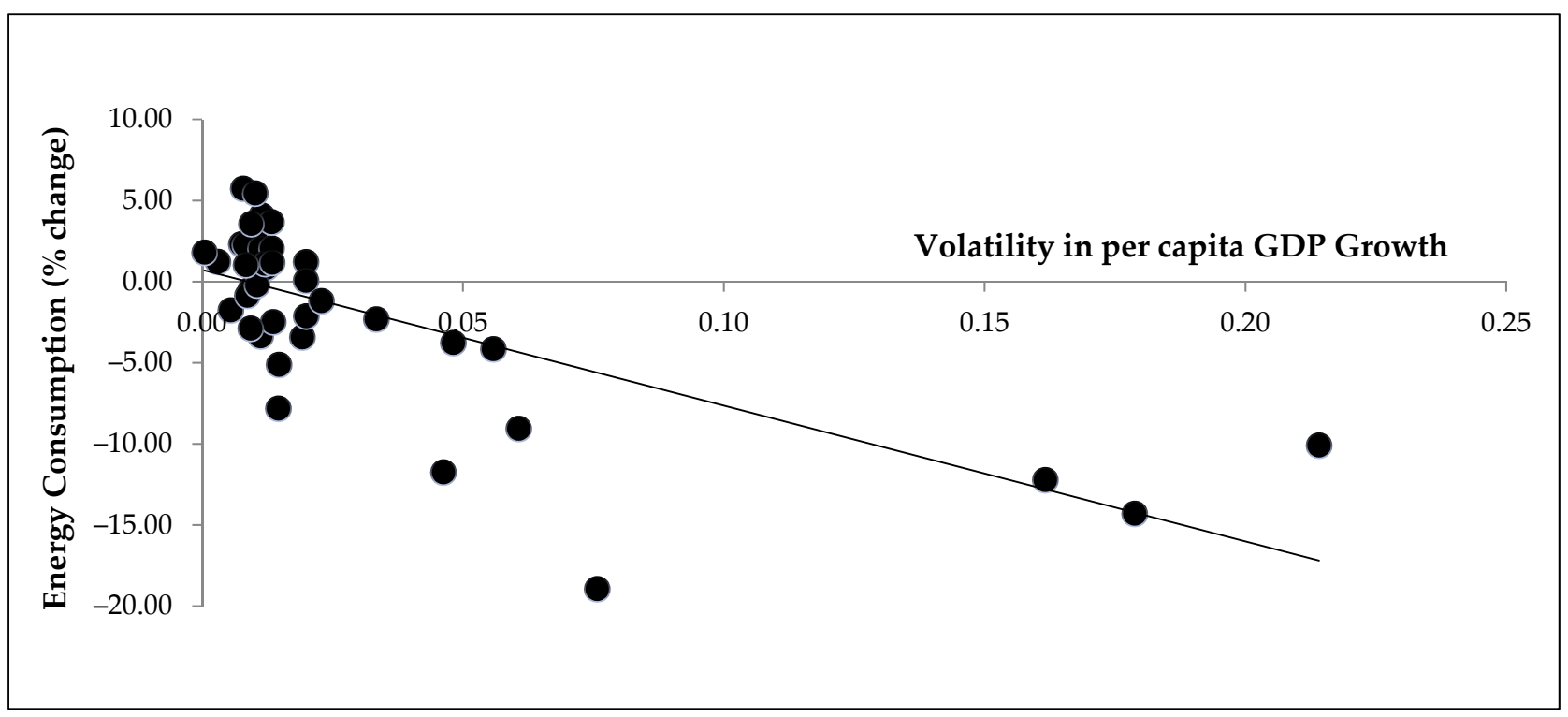

Figure 4. Per-capita income growth volatility and energy consumption growth (averages).

\subsection{Unit Roots and Cointegration}

The general findings from the unit root test (Appendix A Tables A1-A4) demonstrate that the real GDP per capita (RGDPPC) and energy consumption per capita (ECPC) are $\mathrm{I}(1)$ and the volatility measures of both income growth (INVOL) and energy consumption growth $(E V O L)$ are stationary, $\mathrm{I}(0)$. The summary of the cointegration test results is presented in Table 1 (see Appendix A Table A5 for the detailed cointegration test results). The results suggest that there was no long-run equilibrium relationship between the percapita income, the per-capita energy consumption, the volatility of income growth, and the volatility of energy consumption growth in 17 countries. On the other hand, a long-run equilibrium relationship between per-capita income and per-capita energy consumption was established in 31 countries. 
Table 1. Summary of cointegration test results.

\begin{tabular}{cc}
\hline \# of Cointegrating Vectors & Countries \\
$r=2$ & $\begin{array}{c}\text { Bolivia, the Czech Republic, Ecuador, Gabon, Hungary, } \\
\text { Indonesia, Nigeria, Norway, Pakistan, the Philippines, } \\
\text { Portugal, Spain, South Africa, Sudan, Syria, Trinidad and } \\
\text { Tobago, and Venezuela }\end{array}$ \\
& Algeria, Albania, Austria, Australia, Bangladesh, Brazil, \\
Belgium, Canada, China, Chile, Colombia, Denmark, Egypt, \\
France, Finland, Germany, India, Italy, Iran, Japan, New \\
Zealand, the Netherlands, Sri Lanka, South Korea, Sweden, \\
Turkey, Thailand, the UAE, the USA, the UK, and Vietnam
\end{tabular}

\subsection{Long-Run Causal Inferences}

Equation $(3 a, b)$ can be used to gauge the long-run causal relationships between percapita real GDP (income) and per-capita energy consumption. Columns 2 and 3 of Table 2 present the coefficient $\beta$ from the long-run Equation (2) and the corresponding standard errors, respectively. The magnitude of $\beta$ helps to determine if the energy intensity is falling with respect to income. The speed of adjustment coefficients for the per-capita energy consumption equation $\left(\gamma_{21}\right)$ and per-capita real GDP equation $\left(\gamma_{11}\right)$ are reported in columns 4 and 6 of Table 2, respectively. The Yamamoto-Kurozumi test statistic, based on the Chisquared distribution, used to examine the long-run causal relationship between income and energy consumption is reported in column 8 and its reverse causality is reported in column 9 of Table 2. Non-spurious causal inferences require the speed of adjustment for the energy equation $\left(\gamma_{i 1}\right)$ to be negative and the speed of adjustment for the income equation $\left(\gamma_{i 2}\right)$ to be the same sign as $\beta$ (or the opposite sign to $-\beta$ in the cointegrating vector) (Rajaguru and Abeysinghe 2008). The signs of $\gamma_{11}$ and $\gamma_{21}$ were found (as was to be expected) for all countries except for the case of Egypt (the sign of $\gamma_{21}$ was positive (0.11) where it should have been negative). However, the test statistic for the long-run causality from income to energy consumption is insignificant with the Yamamoto-Kurozumi test statistic of 0.03. The wrong sign will not affect the general conclusion of Granger non-causality from income to energy consumption in Egypt. These findings based on the Yamamoto-Kurozumi test and the sign rule suggest that all the long-run causal inferences were non-spurious. Finally, the sign of $\beta$ and the corresponding speed of adjustment coefficients, along with the statistical significance as assessed by the Yamamoto-Kurozumi test, determines the nature of the causal relationship (positive or negative or none). These are summarised in last two columns of Table 2. For the ease of interpretation, the results of the Table 2 are summarised in Table 3. The summary results demonstrate the existence of long-run causality between real GDP per capita and energy consumption per capita in 31 countries. 
Table 2. Long-run causal inferences.

\begin{tabular}{|c|c|c|c|c|c|c|c|c|c|c|}
\hline \multirow[b]{2}{*}{ Countries (1) } & \multirow{2}{*}{$\begin{array}{c}\text { Coefficient } \\
(\beta) \\
(2)\end{array}$} & \multirow[b]{2}{*}{ (se) (3) } & \multicolumn{2}{|c|}{$\begin{array}{c}\text { Per-Capita Energy } \\
\text { Consumption Equation (3b) }\end{array}$} & \multicolumn{2}{|c|}{ Per-Capita Real GDP Equation (3a) } & \multicolumn{2}{|c|}{ Yamamoto-Kurozumi Test } & \multicolumn{2}{|c|}{ Long-Run Causality } \\
\hline & & & $\begin{array}{c}\text { EC }(-1) \\
\left(\gamma_{21}\right) \\
(4)\end{array}$ & $\begin{array}{l}\text { (se) } \\
(5)\end{array}$ & $\begin{array}{c}\text { EC(-1) } \\
\left(\gamma_{11}\right) \\
(6)\end{array}$ & $\begin{array}{c}\text { (se) } \\
(7)\end{array}$ & $\begin{array}{c}\text { RGDPPC } \rightarrow \\
\text { ECPC } \\
\mathbf{( 8 )}\end{array}$ & $\begin{array}{c}\text { ECPC } \rightarrow \\
\text { RGDPPC } \\
\text { (9) }\end{array}$ & $\begin{array}{c}\text { RGDPPC } \rightarrow \\
\text { ECPC } \\
(10)\end{array}$ & $\begin{array}{c}\mathrm{ECPC} \rightarrow \\
\text { RGDPPC } \\
\quad(11)\end{array}$ \\
\hline Albania & $0.13^{* * *}$ & $(0.05)$ & $-0.26^{* * *}$ & $(0.11)$ & 0.18 & $(0.33)$ & $7.16^{* * *}$ & 1.18 & Negative & None \\
\hline Algeria & $0.98^{* * *}$ & $(0.08)$ & -0.0008 & $(0.01)$ & $0.05^{* *}$ & $(0.02)$ & 1.64 & $5.19^{* *}$ & Positive & Positive \\
\hline Australia & $-0.58^{* *}$ & $(0.28)$ & $-0.05^{* * *}$ & $(0.01)$ & -0.06 & $(0.05)$ & $4.08^{* *}$ & 0.67 & Negative & Negative \\
\hline Austria & $7.66^{* * *}$ & $(2.27)$ & -0.00005 & $(0.0002)$ & $0.01^{* * *}$ & $(0.003)$ & 1.34 & $16.02^{* * *}$ & None & Positive \\
\hline Bangladesh & $0.43^{* * *}$ & $(0.02)$ & $-0.05^{* * *}$ & $(0.02)$ & 0.03 & $(0.04)$ & $5.21^{* *}$ & 0.08 & Positive & None \\
\hline Belgium & $-0.13^{* * *}$ & $(0.04)$ & $-0.55^{* * *}$ & $(0.14)$ & 0.07 & $(0.43)$ & $9.74^{* * *}$ & 0.54 & Negative & None \\
\hline Bolivia & - & - & - & $\begin{array}{c}(0.19) \\
-\end{array}$ & - & - & - & - & None & None \\
\hline Brazil & $0.37^{* * *}$ & $(0.06)$ & $-0.002^{* * *}$ & $(0.0004)$ & 0.0008 & $(0.001)$ & $5.96^{* * *}$ & 0.18 & Positive & None \\
\hline Canada & $-0.25^{* * *}$ & $(0.05)$ & $-0.20 * *$ & $(0.09)$ & $-2.22^{* * *}$ & $(0.53)$ & $5.29 * *$ & $9.95^{* * *}$ & Negative & Negative \\
\hline Chile & $-0.47^{* * *}$ & $(0.04)$ & $-0.94^{* * *}$ & $(0.33)$ & -0.95 & $(1.30)$ & $4.45^{* *}$ & 1.09 & Negative & None \\
\hline China & $0.37^{* * *}$ & $(0.11)$ & $-0.005 *$ & $(0.002)$ & $0.05^{* *}$ & $(0.03)$ & 3.48 * & $6.47^{* *}$ & Positive & Positive \\
\hline Colombia & $0.06^{* * *}$ & $(0.03)$ & $0.25^{* * *}$ & $(0.07)$ & 0.13 & $(0.51)$ & $6.35^{* *}$ & 1.53 & Positive & None \\
\hline The Czech Republic & - & - & - & - & - & - & - & - & None & None \\
\hline Denmark & $-0.12^{* *}$ & $(0.05)$ & $-0.06^{* *}$ & $(0.18)$ & -0.65 & $(0.50)$ & $3.36 *$ & 1.41 & Negative & None \\
\hline Egypt & $-0.38^{* * *}$ & $(0.04)$ & 0.11 & $(0.07)$ & $-0.51^{* * *}$ & $(0.18)$ & 0.03 & $50.09 * * *$ & None & Negative \\
\hline Finland & $-0.23^{* *}$ & $(0.09)$ & $-0.15^{* *}$ & $(0.06)$ & -0.01 & $(0.13)$ & $26.10^{* * *}$ & 0.86 & Negative & None \\
\hline France & $0.81^{* * *}$ & $(0.02)$ & $-0.03^{* *}$ & $(0.01)$ & $0.09^{* *}$ & $(0.03)$ & 3.45 * & $4.82 * *$ & Positive & Positive \\
\hline Gabon & - & - & - & - & - & - & - & - & None & None \\
\hline Germany & $-0.15^{* * *}$ & $(0.03)$ & $-0.31^{* * *}$ & $(0.10)$ & -0.33 & $(0.32)$ & $14.15^{* *}$ & 0.26 & Negative & None \\
\hline Hungary & - & - & - & - & - & - & - & - & None & None \\
\hline India & $0.97^{* * *}$ & $(0.03)$ & -0.004 & $(0.003)$ & $0.09^{* * *}$ & $(0.02)$ & 1.45 & $6.38^{* *}$ & None & Positive \\
\hline Indonesia & - & - & - & - & - & - & - & - & None & None \\
\hline Iran & $-0.17^{* * *}$ & $(0.02)$ & $-0.14^{* * *}$ & $(0.04)$ & $0.69^{* * *}$ & $(0.017)$ & $14.39 * * *$ & $10.56^{* * *}$ & Negative & Negative \\
\hline Italy & $-0.32^{* * *}$ & $(0.11)$ & $-0.06^{* * *}$ & $(0.02)$ & 0.14 & $(0.14)$ & $4.05^{* *}$ & 1.73 & Negative & None \\
\hline Japan & $-0.17^{* * *}$ & $(0.03)$ & $-0.49^{* * *}$ & $(0.11)$ & -0.07 & $(0.82)$ & $3.94^{* *}$ & 0.68 & Negative & None \\
\hline Korea & $1.82^{* * *}$ & $(0.07)$ & -0.11 & $(0.12)$ & $0.65^{* * *}$ & $(0.16)$ & 1.58 & $10.86^{* * *}$ & None & Positive \\
\hline The Netherlands & $-0.10^{* * *}$ & $(0.05)$ & $-0.39^{* * *}$ & $(0.14)$ & 0.004 & $(0.34)$ & $4.51^{* *}$ & 1.66 & Negative & None \\
\hline New Zealand & $-0.71^{* * *}$ & $(0.14)$ & $-0.06^{*}$ & $(0.03)$ & $-0.34^{* * *}$ & $(0.09)$ & $2.81 *$ & $8.27^{* * *}$ & Negative & Negative \\
\hline Nigeria & - & - & - & - & - & - & - & - & None & None \\
\hline
\end{tabular}


Table 2. Cont.

\begin{tabular}{|c|c|c|c|c|c|c|c|c|c|c|}
\hline \multirow[b]{2}{*}{ Countries (1) } & \multirow{2}{*}{$\begin{array}{c}\text { Coefficient } \\
(\beta) \\
(2)\end{array}$} & \multirow[b]{2}{*}{ (se) (3) } & \multicolumn{2}{|c|}{$\begin{array}{c}\text { Per-Capita Energy } \\
\text { Consumption Equation (3b) }\end{array}$} & \multicolumn{2}{|c|}{ Per-Capita Real GDP Equation (3a) } & \multicolumn{2}{|c|}{ Yamamoto-Kurozumi Test } & \multicolumn{2}{|c|}{ Long-Run Causality } \\
\hline & & & $\begin{array}{c}\text { EC }(-1) \\
\left(\gamma_{21}\right) \\
(4)\end{array}$ & $\begin{array}{l}\text { (se) } \\
(5)\end{array}$ & $\begin{array}{c}\text { EC(-1) } \\
\left(\gamma_{11}\right) \\
(6)\end{array}$ & $\begin{array}{l}\text { (se) } \\
(7)\end{array}$ & $\begin{array}{c}\text { RGDPPC } \rightarrow \\
\text { ECPC } \\
(8)\end{array}$ & $\begin{array}{l}\text { ECPC } \rightarrow \\
\text { RGDPPC } \\
\text { (9) }\end{array}$ & $\begin{array}{c}\text { RGDPPC } \rightarrow \\
\text { ECPC } \\
(10)\end{array}$ & $\begin{array}{c}\mathrm{ECPC} \rightarrow \\
\text { RGDPPC } \\
\quad(11)\end{array}$ \\
\hline Norway & - & - & - & - & - & - & - & - & None & None \\
\hline Pakistan & - & - & - & - & - & - & - & - & None & None \\
\hline Philippines & - & - & - & - & - & - & - & - & None & None \\
\hline Portugal & - & - & - & - & - & - & - & - & None & None \\
\hline South Africa & - & - & - & - & - & - & - & - & None & None \\
\hline Spain & - & - & - & - & - & - & - & - & None & None \\
\hline Sri Lanka & $0.74^{* * *}$ & $(0.03)$ & -0.02 & $(0.02)$ & $0.13^{* * *}$ & $(0.04)$ & 2.55 & $11.62 * * *$ & None & Positive \\
\hline Sudan & - & - & - & - & - & - & - & - & None & None \\
\hline Sweden & $-0.20^{* * *}$ & $(0.05)$ & $-0.51^{* * *}$ & $(0.11)$ & -0.26 & $(0.38)$ & $8.06^{* * *}$ & 2.54 & Negative & None \\
\hline Syrian & - & - & - & - & - & - & - & - & None & None \\
\hline Thailand & $-0.72^{* * *}$ & $(0.10)$ & $0.10^{* *}$ & $(0.05)$ & -0.09 & $(0.15)$ & $7.11^{* *}$ & 0.29 & Negative & None \\
\hline $\begin{array}{c}\text { Trinidad and } \\
\text { Tobago }\end{array}$ & - & - & - & - & - & - & - & - & None & None \\
\hline UK & $-0.07^{* * *}$ & $(0.01)$ & $-0.26^{* *}$ & $(0.11)$ & $-1.99^{* * *}$ & $(0.71)$ & $9.53 * *$ & $60.31^{* * *}$ & Negative & Negative \\
\hline USA & $-0.32^{* * *}$ & $(0.12)$ & $-0.21^{* *}$ & $(0.08)$ & -0.05 & $(0.33)$ & $6.67^{* *}$ & 1.63 & Negative & None \\
\hline Venezuela & - & - & - & - & - & - & - & - & None & None \\
\hline Vietnam & $-0.49^{* * *}$ & $(0.03)$ & -0.02 & $(0.02)$ & $0.79 * * *$ & $(0.06)$ & 1.37 & $17.74^{* * *}$ & None & Negative \\
\hline
\end{tabular}

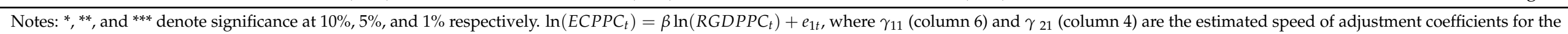

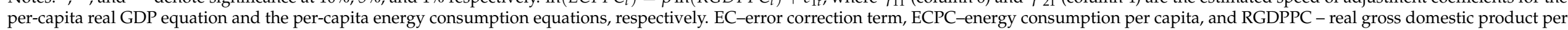

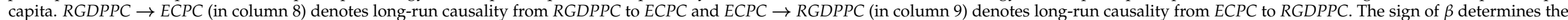
nature of the long-run causal relationships (positive, negative, or none). 
Table 3. Summary of long-run Granger causality results.

\begin{tabular}{ccc}
\hline Causality & Positive & Negative \\
\hline RGDPPC $\rightarrow$ ECPC & $\begin{array}{c}\text { Albania, Bangladesh, Brazil, } \\
\text { Columbia }\end{array}$ & $\begin{array}{c}\text { Belgium, Chile, Denmark, } \\
\text { Finland, Germany, Italy, Japan, } \\
\text { the Netherlands, Sweden, } \\
\text { Thailand, the USA }\end{array}$ \\
\hline ECPC $\rightarrow$ RGDPPC & $\begin{array}{c}\text { Austria, India, South Korea, } \\
\text { Sri Lanka }\end{array}$ & Egypt, Vietnam \\
\hline $\begin{array}{c}\text { Ro causality between } \leftrightarrow \text { ECPC } \\
\text { RGDPPC and ECPC }\end{array}$ & $\begin{array}{c}\text { Algeria, China, France, Turkey } \\
\text { Bolivia, Ecuador, the Czech Republic, Gabon, Indonesia, Hungary, } \\
\text { Norway, Nigeria, Pakistan, Portugal, the Philippines, Spain, } \\
\text { South Africa, Sudan, Syria, Venezuela, Trinidad and Tobago }\end{array}$ \\
\hline Notes: This is based on the results from Table 1.
\end{tabular}

Overall, the results validate different causal relationships for different countries. The results show negative unidirectional long-run causality from income to energy consumption in Belgium, Chile, Denmark, Finland, Germany, Italy, Japan, the Netherlands, Sweden, Thailand, and the USA. This implies that increasing income decreases energy consumption and hence energy intensity has been significantly decreasing. In contrast with the above results, Cheng observed evidence for the causality from energy consumption to economic growth for Japan and many have observed mixed evidence in the case of the United States (see Kraft and Kraft 1978; Akarca and Long 1980; Yu and Hwang 1984; Abosedra and Baghestani 1989; Yu and Jin 1992; Stern 1993; Cheng 1995; Stern 2000; Soytas et al. 2007; Ewing et al. 2007; Payne 2009; Bowden and Payne 2009; Fallahi 2011). These results are according to the expectations that the magnitude of the energy-growth nexus has changed in favour of falling energy intensity in the past one and a half decades. On the other hand, a negative causality from energy consumption to growth also confirms the implied explanation of falling energy intensity in Egypt and Vietnam. Furthermore, a range of countries, including Australia, Canada, Iran, New Zealand, the UAE, and the UK, exhibit negative bi-directional causality, which generates the multiplier effect on energy consumption in the realm of falling energy intensity.

As confirmed through the Yamamoto and Kurozumi (2006) test and the sign rule developed by Rajaguru and Abeysinghe (2008), the overall evidence confirms the long-run energy-growth nexus. It indicates falling energy intensity in most sample countries. The long-run Equation (2) can be written as $\ln \left(E C P P C_{t}\right)=\beta \ln \left(R G D P P C_{t}\right)+e_{1 t}$. It can be re-rearranged to represent its results in energy intensity form as a function of real GDP per capita: $\ln \left(E C P P C_{t} / R G D P P C_{t}\right)=(\beta-1) \ln \left(R G D P P C_{t}\right)+e_{1 t}$. The energy intensity $E C P P C_{t} / R G D P P C_{t}$ falls with respect to income when $\beta<1$. Likewise, causality from consumption to income requires $\beta>1$. Correspondingly, concerning unidirectional causality from income to energy consumption, evidence shows that $\beta<1$, with significantly falling energy intensity in 15 countries. Furthermore, we can decompose the results into two broad categories $0<\beta<1$ and $\beta<0$. When the coefficient of income is between 0 and 1 , regarding the conservation hypothesis, increasing income leads to a smaller increase in energy consumption. The above has been witnessed in Albania, Bangladesh, Brazil, and Columbia. Furthermore, coefficients of income with $\beta<0$ have been observed in Belgium, Denmark, Chile, Finland, Italy, Germany, Japan, the Netherlands, Thailand, Sweden, and the USA. Therefore, the estimated coefficient of $\beta$ ranging from $0<\beta<1$ and $\beta<0$ confirm the conservation with falling energy intensity in all corresponding countries. The above findings can be broadly reconciled with earlier studies reporting that income coefficients of energy consumption significantly decrease with the increasing development of corresponding economies (Joyeux and Ripple 2011; Medlock and Soligo 2021; Van Benthem and Romani 2009; Judson and Orphanides 1999). 
The results confirm the causality from energy consumption to income in Austria, Egypt, India, South Korea, Sri Lanka, and Vietnam, where energy use leads per capita income. Egypt and Vietnam demonstrate that increasing energy consumption significantly decreases income-supporting conservation policies. Further results from Austria and South Korea show that a small increase in energy consumption increases income by many folds, strongly supporting the conjecture of falling energy intensity. However, results from countries such as India and Sri Lanka indicate that increasing energy consumption increases income less proportionately-this is mainly because of energy-intensive methods of production with high energy leakages. Furthermore, we found evidence supporting the feedback causal relationship between income and energy consumption in Australia, Algeria, China, Canada, France, New Zealand, Iran, Turkey, the UK, and the UAE. All the above countries have an estimated $\beta$ of income to energy consumption that is less than one, implying a significant decrease in energy intensity in those countries. This is consistent with the results described in Wang et al. (2011a) and Zhixin and Xin (2011) for China and Erdal et al. (2008) and Acaravci (2010) for Turkey. The remaining 17 countries show no evidence of the relationship between energy consumption and economic growth.

\subsection{Short-Run Causal Inferences}

We analysed the short-run dynamic relationship among variables with a particular focus on energy consumption and income volatilities. The aspect of energy consumption and income volatility has been grossly ignored in the energy-growth literature. A summary of the short-run causality test results is presented in Table 4 . The relevant test statistics and the corresponding levels of significance are presented in Appendix A Table A6.

Table 4. Short-run Granger causality results.

\begin{tabular}{|c|c|c|}
\hline Causality & Positive & Negative \\
\hline $\mathrm{RGDPPC} \rightarrow \mathrm{ECPC}$ & $\begin{array}{l}\text { Bolivia, Canada, Ecuador, Gabon, Germany, } \\
\text { Hungary, India, Indonesia, Iran, Japan, the } \\
\text { Netherlands, Pakistan, Portugal, Spain, Sweden, } \\
\text { Syria, Thailand, Venezuela }\end{array}$ & Albania, Belgium, Sudan \\
\hline INVOL $\rightarrow$ ECPC & & $\begin{array}{l}\text { Albania, Algeria, Belgium, Bolivia, Brazil, Canada, } \\
\text { Chile, Colombia, Denmark, Ecuador, France, } \\
\text { Gabon, Germany, Hungary, Indonesia, Iran, Japan, } \\
\text { Korea, the Netherlands, Nigeria, the Philippines, } \\
\text { Portugal, South Africa, Spain, Syria, the UAE, the } \\
\text { UK, the USA }\end{array}$ \\
\hline $\mathrm{EVOL} \rightarrow \mathrm{ECPC}$ & Algeria, & $\begin{array}{l}\text { Brazil, Ecuador, Finland, Germany, the } \\
\text { Netherlands, Nigeria, Portugal, Syria, Trinidad } \\
\text { and Tobago, Turkey, the UAE, the USA }\end{array}$ \\
\hline $\mathrm{ECPC} \rightarrow \mathrm{RGDPPC}$ & $\begin{array}{c}\text { Canada, China, France, Gabon, Hungary, Iran, } \\
\text { Italy, South Korea, Pakistan, the Philippines, } \\
\text { Portugal, South Africa, Spain, the UK, the USA, } \\
\text { Venezuela, Vietnam }\end{array}$ & \\
\hline $\mathrm{INVOL} \rightarrow \mathrm{RGDPPC}$ & $\begin{array}{c}\text { Austria, India, South Korea, Philippines, Sri } \\
\text { Lanka, Turkey }\end{array}$ & $\begin{array}{c}\text { Albania, Algeria, Canada, Chile, the Czech } \\
\text { Republic, Indonesia, Iran, New Zealand, Portugal, } \\
\text { South Africa, Spain, the UK, Vietnam }\end{array}$ \\
\hline $\mathrm{EVOL} \rightarrow \mathrm{RGDPPC}$ & Albania, Algeria, Austria, France, Portugal, Syria & $\begin{array}{c}\text { Chile, China, Hungary, Iran, Italy, South Korea, } \\
\text { Norway, Venezuela }\end{array}$ \\
\hline $\mathrm{ECPC} \rightarrow \mathrm{INVOL}$ & Canada, Indonesia, Italy, Spain, Turkey, the UK & China, Hungary, Japan, Thailand, the UAE \\
\hline
\end{tabular}


Table 4. Cont.

\begin{tabular}{|c|c|c|}
\hline Causality & Positive & Negative \\
\hline RGDPPC $\rightarrow$ INVOL & $\begin{array}{l}\text { Belgium, Bolivia, Chile, China, the Czech } \\
\text { Republic, the UK }\end{array}$ & $\begin{array}{l}\text { Albania, Algeria, Australia, Austria, Brazil, } \\
\text { Canada, Columbia, Denmark, Ecuador, Finland, } \\
\text { France, Gabon, India, Indonesia, Iran, Italy, the } \\
\text { Netherlands, Portugal, South Africa, Spain, Syria, } \\
\text { Thailand, Trinidad and Tobago, Turkey, the UAE, } \\
\text { Venezuela, Vietnam }\end{array}$ \\
\hline $\mathrm{EVOL} \rightarrow \mathrm{INVOL}$ & $\begin{array}{l}\text { Albania, Austria, China, Germany, Indonesia, } \\
\text { Japan, Pakistan, Portugal, South Africa, Sudan, } \\
\text { Syria, the UK }\end{array}$ & \\
\hline $\mathrm{ECPC} \rightarrow \mathrm{ECVOL}$ & Spain, Sri Lanka, Turkey, & $\begin{array}{c}\text { Albania, Algeria, China, the Czech Republic, } \\
\text { Ecuador, Iran, the Netherlands, Nigeria, Norway, } \\
\text { Portugal, Syria, Thailand, the UK }\end{array}$ \\
\hline RGDPPC $\rightarrow$ EVOL & $\begin{array}{c}\text { Albania, Canada, Ecuador, India, Portugal, Syria, } \\
\text { the USA, Vietnam }\end{array}$ & Bangladesh, Finland, Nigeria, Pakistan \\
\hline $\mathrm{INVOL} \rightarrow$ EVOL & $\begin{array}{l}\text { Bolivia, Colombia, the Czech Republic, Denmark, } \\
\text { Germany, India, New Zealand, Nigeria, Norway, } \\
\text { Pakistan, Portugal, Sudan, Syria, Thailand, the } \\
\text { UK, and the USA }\end{array}$ & \\
\hline
\end{tabular}

The results show 12 countries with short-run unidirectional causality from real GDP per-capita growth to energy consumption growth, nine countries with reverse causality, and another nine countries with bi-directional causality. The results show that increasing energy consumption increases income in China, France, Italy, the Philippines, South Africa, South Korea, the UK, the USA, and Vietnam. The remaining 18 countries show no short-run relationship. In summary, we found 44 countries with either long-run (short-run) causality in at least one direction. However, the remaining four countries (the Czech Republic, Nigeria, Norway, and Trinidad and Tobago) showed no evidence causal relationship between income and energy consumption in both the short-run and long-run analysis.

The uncertainty (volatility) in income growth is expected to reduce energy consumption. The results show a significant decrease in the energy use in response to increasing the income growth volatilities in 28 countries, including Albania, Algeria, Belgium, Bolivia, Brazil, Canada, Chile, Colombia, Denmark, Ecuador, France, Gabon, Germany, Hungary, Indonesia, Iran, Japan, Korea, Netherlands, Nigeria, the Philippines, Portugal, South Africa, Spain, Syria, the UAE, the UK, and the USA. These results indicate that uncertainty (volatility) in income growth discourages expenditure by lowering energy consumption. The results for Canada, Chile, the Czech Republic, Indonesia, Iran, New Zealand, Portugal, Spain, the UK, and Vietnam show evidence in support of Bernanke (1983), Pindyck (1991) and Hnatkovska and Loayza (2005). They indicate that growth is negatively influenced by income volatility. We also found evidence supporting the claims of Black (1987), indicating that growth is positively related to income volatility. In general, increases in income tend to lower the income volatilities in many countries, rather than increasing income volatility.

On the other hand, the results also indicate that the volatilities in energy use growth are significantly related to income changes in China, Italy, Thailand, and Turkey. Furthermore, the results suggest that income growth volatilities increase volatilities in energy consumption growth in countries such as Bolivia, the Czech Republic, Denmark, Ecuador, Germany, India, New Zealand, Nigeria, Norway, Portugal, Thailand, and the USA. On the other hand, we found that the volatilities of energy consumption growth increased volatilities in income in Albania, Austria, China, Hungary, Indonesia, Japan, and South Africa. Interestingly, feedback effects of income and energy consumption growth volatilities were observed in Pakistan, Sudan, Syria, and the United Kingdom. The short-run negative effects of income volatility are usually countered by compensating people with subsidies 
to households and producers from many developing countries in order to smooth energy consumption behaviour.

We find the presence of long-run and/or short-run causality between growth and energy use in terms of energy intensity in a majority of the 48 countries included in the sample. There are only five countries exhibiting no causality between income and energy use. We observe 13 countries showing a valid causality running from energy consumption to economic growth and this has been confirmed through falling energy intensity. The above findings, in general, align with the sustainability argument that income growth does not require a proportional increase in energy consumption. Moreover, six countries observe causality from economic growth to energy use, concurrently with falling energy intensity. However, the falling energy intensity together with causality from economic growth to energy consumption indicate energy efficient methods of production, perhaps on the back of successful energy conservation policies. In the same vein, our results lend support lend support to the feedback relationships, in terms of falling energy intensity in 10 countries.

\section{Concluding Remarks and Policy Implications}

This study investigates energy-intensity through the energy-growth framework. We found that the historical evolution of energy intensity provides a new explanation for the energy-growth nexus, unlike the previous literature that merely relies on causality between the two. Furthermore, this study offers the unique feature of expressing the energy-growth nexus in terms of volatility analysis, which adds great value to the existing literature on this topic.

As confirmed through the Yamamoto-Kurozumi test, the evidence suggests the presence of long-run and/or short-run causality between growth and energy use in terms of energy intensity in 43 out of all the 48 countries included in the sample. The remaining five countries were confirmed to exhibit no causality between income and energy use. In particular, 13 countries appear to indicate a valid causal relationship from energy use to economic growth, with falling energy intensity captured through $\beta<1$. The above results indirectly confirm the sustainability argument that income growth does not require a proportional increase in energy consumption in those countries. In addition, six countries showed the presence of causality from economic growth to energy use, with falling energy intensity. The above findings indicate improved methods of production, successful energy conservation policies, or switching to alternative energy sources. In Austria and South Korea the intensity coefficient appeared to be $\beta>1$. The results also lend support to the feedback causal relationships, in terms of falling energy intensity in 10 countries. Policymakers and applied researchers may benefit from the current findings in relation to energy conservation efforts to overcome the serious environmental issues that the world is passing through. There are only five countries exhibiting no causality between income and energy use. It is possible that these countries may switch between the positive causal relationship and negative causal relationship in the sub-sample periods. These effects are likely to be nullified (i.e., no causality between the energy consumption and income) when the model is estimated for the full sample. Future research could extend this framework to the regime-switching approach to analyse the time-varying nature of the causal inferences. It will help policy makers to align themselves and so maintain the optimal energy mix to achieve the sustainable economic growth. Countries with a unidirectional causality from income to energy consumption may contribute to the fight against global warming directly implementing energy conservation measures. On the other hand, countries with a unidirectional causality from energy consumption to income may focus on technological developments and mitigation policies. However, for the countries with the feedback causal relationships, a balanced combination of alternative policies seems to be appropriate (see Soytas and Sari 2006).

Overall, energy efficiency policies are becoming progressively more important all over the world. Our results reveal that (for the majority of countries) energy consumption decreases or moderately increases along with increasing income; hence, energy efficiency 
has increased over the period of study. Thus, consuming less energy reduces the demand for available energy resources, such as fossil fuels. Energy efficiency programmes, however, ought to be created based on the promotion of suitable schemes. For instance, policymakers should promote incentive pricing for a successful energy efficiency plan. In the same vein, packages of measures including financial incentives and regulations should be implemented simultaneously, rather than one after the other. Moreover, public-private partnerships should be promoted in order to achieve set targets of energy efficiency. A favourable and stable institutional framework is also needed in order to ensure policy continuity with quantitative energy efficiency targets. Furthermore, in order to be efficient, energy efficiency strategies should be supervised regularly and adequately enforced. Certification and testing facilities should be available to promote innovations in energyrelated tools and appliances. Innovative measures should be promoted in disadvantaged countries based on the experiences of developed countries. Finally, the successful implementation of energy policies reduces energy volatilities, which are strongly linked with income volatilities and vice versa.

Regarding short-run causality, the results also confirm falling energy intensity, along with the causal relationship between economic growth and energy use. The results indicate a significant decrease in energy use in response to increasing income growth volatility. Furthermore, the results suggest that income volatilities increase volatilities in energy consumption in a few countries. This occurs because the short-run negative effects of income volatility are usually countered by the provision of compensation with subsidies to households and producers in many developing countries to smooth energy consumption behaviour.

The country-specific long-run and short-run causal inferences are found to be not specific to any cluster of countries. In other words, the causal inferences are not robust to any regional countries. The results could be misleading if we assume homogeneity across the countries or regions if the model is estimated in a panel framework. Furthermore, it reconfirms the argument of Menegaki and Tsani (2018) that country-specific estimates are mostly different from the results of pooled (panel) regression models, such as those discussed in the main study by Apergis and Payne (2012). The policy recommendations should be made at the country level rather than the regional level.

In this study, we assumed that the volatilities of economic growth and energy consumption growth had symmetrical effects on income and energy consumption. The causal effects from volatility to energy consumption could be asymmetrical for both positive and negative deviations. Future studies could incorporate such time-varying asymmetrical non-linear causal relationships into their analysis. The study could also be extended to analyse the role of renewable energy and related policies on sustainable economic growth.

Author Contributions: Conceptualisation, S.U.K. and G.R.; methodology, G.R.; software, G.R.; validation, S.U.K. and G.R.; formal analysis, S.U.K. and G.R.; investigation, S.U.K. and G.R.; resources, S.U.K. and G.R.; data curation, S.U.K. and G.R.; writing-original draft preparation, S.U.K. and G.R.; writing - review and editing, S.U.K. and G.R.; visualisation, G.R.; supervision, G.R.; project administration, G.R. All authors have read and agreed to the published version of the manuscript.

Funding: This research received no external funding.

Data Availability Statement: We used the World Development Indicators (2017) as the primary source of data.

Acknowledgments: We acknowledge feedback and comments offered by the audience of a seminar at the Bond Business School, Econometrics Society Australasian Meeting, and the Australian Conference of Economists 2019. We have also benefited from the comments and suggestions received from Robert Wrathall, Bond Business School, Australia. The views expressed here are those of authors and not their affiliated institutions.

Conflicts of Interest: The authors declare no conflict of interest. 


\section{Appendix A}

Table A1. Unit root test-real GDP per capita (RGDPPC).

\begin{tabular}{|c|c|c|c|c|c|c|c|c|c|c|}
\hline \multirow{2}{*}{ Countries } & \multicolumn{5}{|c|}{ Level } & \multicolumn{5}{|c|}{ First Difference } \\
\hline & ADF & PP & KPSS & Breakpoint & Break & ADF & PP & KPSS & Breakpoint & Break \\
\hline Albania & -2.36 & -1.42 & $0.16^{* *}$ & -3.79 & 2003 & $-3.79 * * *$ & $-3.03^{* * *}$ & 0.32 & $-5.29 * *$ & 1990 \\
\hline Algeria & -2.63 & -1.66 & $0.15^{* *}$ & -3.02 & 1990 & $-2.98^{* *}$ & $-4.52 * * *$ & 0.15 & $-4.64 * *$ & 1979 \\
\hline Australia & -1.74 & -1.99 & $0.19 * *$ & -3.55 & 2000 & $-5.35^{* * *}$ & $-5.35 * * *$ & 0.11 & $-6.33^{* * *}$ & 2001 \\
\hline Austria & -2.11 & -1.44 & $0.18^{* *}$ & -2.37 & 1981,1986 & $-3.02 * *$ & $-3.17^{* *}$ & 0.19 & $-8.97^{* * *}$ & 1985 \\
\hline Bangladesh & -2.47 & -2.04 & 0.14 * & -3.72 & 2003 & $-4.59 * * *$ & $-4.59 * * *$ & 0.08 & $-4.81 * *$ & 2002 \\
\hline Belgium & -1.01 & -0.89 & $0.15^{* *}$ & -3.63 & 1980 & $-3.05^{* *}$ & $-3.08^{* *}$ & 0.26 & $-6.94^{* * *}$ & 2000 \\
\hline Bolivia & -2.16 & -2.27 & $0.17^{* *}$ & -2.02 & 1999 & $-4.29 * * *$ & $-4.35^{* * *}$ & 0.19 & $-4.89 * *$ & 2003 \\
\hline Brazil & -2.53 & -2.13 & $0.14 *$ & -3.88 & 1986 & $-4.25^{* * *}$ & $-4.24^{* * *}$ & 0.09 & $-4.77^{* *}$ & 1985 \\
\hline Canada & -2.35 & -2.27 & $0.17 * *$ & -3.35 & 1992 & $-4.65^{* * *}$ & $-4.66^{* * *}$ & 0.08 & $-5.69 * * *$ & 1975 \\
\hline Chile & -2.32 & -2.57 & $0.18^{* *}$ & -3.32 & 1997 & $-6.95^{* * *}$ & $-6.95^{* * *}$ & 0.07 & $-16.87^{* * *}$ & 1998 \\
\hline China & -2.34 & -2.25 & $0.18^{* *}$ & -3.01 & 1986 & $-6.33^{* * *}$ & $-6.34^{* * *}$ & 0.19 & $-9.92^{* * *}$ & 1992 \\
\hline Colombia & -1.68 & -1.65 & $0.17^{* *}$ & -3.11 & 1992 & $-4.54^{* * *}$ & $-4.56^{* * *}$ & 0.18 & $-5.89^{* * *}$ & 1993 \\
\hline $\begin{array}{l}\text { The Czech } \\
\text { Republic }\end{array}$ & -2.08 & -1.36 & $0.15^{* *}$ & -2.71 & 1985 & $-4.53^{* * *}$ & $-4.53^{* * *}$ & 0.23 & $-5.06^{* * *}$ & 2012 \\
\hline Denmark & -2.52 & -2.34 & 0.14 * & -2.68 & 1980 & $-4.79 * * *$ & $-4.69^{* * *}$ & 0.13 & $-5.37^{* * *}$ & 1985 \\
\hline Ecuador & -2.39 & -1.74 & $0.12 *$ & -3.26 & 1987 & $-2.91 *$ & $-3.13^{* *}$ & 0.16 & $-4.31 *$ & 1979 \\
\hline Egypt & -1.71 & -1.82 & $0.16^{* *}$ & -3.73 & 1985 & $-4.25 * * *$ & $-4.36^{* * *}$ & 0.16 & $-4.94 * *$ & 1994 \\
\hline Finland & -1.44 & -1.48 & 0.14 * & -2.93 & 1982 & $-4.31^{* * *}$ & $-4.44^{* * *}$ & 0.19 & $-6.34^{* * *}$ & 1986 \\
\hline France & -2.66 & -2.27 & $0.17^{* *}$ & -2.22 & 2004 & $-4.66^{* * *}$ & $-4.66^{* * *}$ & 0.06 & $-5.25 * * *$ & 1986 \\
\hline Gabon & -1.8 & -1.8 & $0.22 * * *$ & -2.92 & 1986 & $-5.95 * * *$ & $-6.11^{* * *}$ & 0.29 & $-7.11^{* * *}$ & 1983 \\
\hline Germany & -1.93 & -1.21 & $0.21^{* * *}$ & -3.05 & 1985 & $-4.92^{* * *}$ & $-4.84^{* * *}$ & 0.31 & $-5.55 * * *$ & 1981 \\
\hline Hungary & -2.99 & -2.06 & 0.12 * & -3.43 & 1985 & $-4.47^{* * *}$ & $-4.37^{* * *}$ & 0.14 & $-4.92 * *$ & 1992 \\
\hline India & -0.58 & -0.26 & $0.22 * *$ & -3.94 & 1974 & $-4.91 * * *$ & $-4.61^{* * *}$ & 0.13 & $-7.43^{* * *}$ & 1975 \\
\hline Indonesia & -1.93 & -1.37 & 0.12 * & -4.11 & 1987 & $-2.92 *$ & $-2.97^{* *}$ & 0.21 & $-4.29 *$ & 1994 \\
\hline Iran & -1.88 & -0.82 & $0.23^{* * *}$ & -2.88 & 1978 & $-3.26^{* *}$ & $-2.64 *$ & 0.31 & $-5.23 * * *$ & 1978 \\
\hline Italy & -0.89 & -1.05 & $0.16^{* *}$ & -1.04 & 2001 & $-2.86 *$ & $-5.25 * * *$ & 0.3 & $-5.89 * * *$ & 1996 \\
\hline Japan & -1.75 & $-3.33^{*}$ & $0.15^{* *}$ & -2.92 & 2004 & $-6.64^{* * *}$ & $-6.37^{* * *}$ & 0.25 & $-7.55^{* * *}$ & 2008 \\
\hline Korea South & -3.12 & -2.17 & 0.14 * & -4.12 & 1985 & $-4.81^{* * *}$ & $-4.71 * * *$ & 0.31 & $-5.42^{* * *}$ & 1981 \\
\hline The Netherlands & $-3.38 *$ & -2.58 & $0.15^{* *}$ & -3.71 & 1985 & $-5.00 * * *$ & $-4.86^{* * *}$ & 0.08 & $-5.53 * * *$ & 1981 \\
\hline New Zealand & -3.11 & -2.58 & $0.12 *$ & -3.58 & 2000 & $-4.22 * * *$ & $-4.13^{* * *}$ & 0.06 & $-4.62 * * *$ & 1999 \\
\hline Nigeria & -3.11 & -2.32 & $0.16^{* *}$ & -3.89 & 1984 & $-4.81^{* * *}$ & $-4.54^{* * *}$ & 0.08 & $-5.88^{* * *}$ & 1993 \\
\hline Norway & -3.11 & -2.51 & $0.15^{* *}$ & -3.57 & 1985 & $-4.97^{* * *}$ & $-4.92 * * *$ & 0.09 & $-5.34^{* * * *}$ & 1981 \\
\hline Pakistan & -2.26 & -2.07 & $0.13 *$ & - & - & $-2.92 *$ & $-2.84 *$ & 0.28 & - & - \\
\hline Philippines & -0.78 & -0.99 & $0.16^{* *}$ & -2.77 & 1988 & $-5.89 * * *$ & $-6.03^{* * *}$ & 0.24 & $-7.46^{* * *}$ & 1991 \\
\hline Portugal & -3.03 & -2.5 & $0.18^{* *}$ & -3.72 & 1980 & $-4.95 * * *$ & $-4.73^{* * *}$ & 0.06 & $-6.29^{* * *}$ & 1986 \\
\hline South Africa & -1.38 & -0.47 & $0.24^{* * *}$ & -3.42 & 1985 & $-5.03^{* * *}$ & $-4.83^{* * *}$ & 0.33 & $-5.77^{* * *}$ & 1995 \\
\hline Spain & $-5.61^{* * *}$ & $-5.52^{* * *}$ & 0.05 & $-4.69^{* *}$ & 1986 & - & - & - & - & - \\
\hline Sri Lanka & -0.64 & -0.71 & $0.19 * *$ & -2.56 & 1978 & $-6.81^{* * *}$ & $-6.89^{* * *}$ & 0.32 & $-11.02^{* * *}$ & 1978 \\
\hline Sudan & -2.51 & -1.81 & $0.15^{* *}$ & -3.71 & 1985 & $-4.94^{* * *}$ & $-4.87^{* * *}$ & 0.18 & $-5.54^{* * *}$ & 1981 \\
\hline Sweden & -2.98 & -2.14 & $0.19^{* *}$ & -3.92 & 2000 & $-4.28^{* * *}$ & $-4.32 * * *$ & 0.24 & $-4.84^{* *}$ & 1984 \\
\hline Syrian & -3.06 & -3.05 & $0.13^{* *}$ & -1.71 & 1982 & $-5.27^{* * *}$ & $-5.11 * * *$ & 0.07 & $-8.53^{* * *}$ & 1973 \\
\hline Thailand & -1.39 & -1.09 & $0.17^{* *}$ & -2.79 & 1981 & $-4.49^{* * *}$ & $-4.52 * * *$ & 0.32 & $-5.94^{* * *}$ & 1984 \\
\hline $\begin{array}{c}\text { Trinidad and } \\
\text { Tobago }\end{array}$ & -2.29 & -1.95 & $0.12 *$ & -3.34 & 1979 & $-3.74^{* * *}$ & $-3.74^{* * *}$ & 0.12 & $-4.74^{* *}$ & 1980 \\
\hline Turkey & -3.05 & -2.58 & $0.13 *$ & -3.38 & 2001 & $-5.26^{* * *}$ & $-5.08^{* * *}$ & 0.05 & $-5.69 * * *$ & 1992 \\
\hline UAE & -2.79 & -2.38 & 0.12 * & -2.45 & 1986 & $-4.91 * * *$ & $-4.95 * * *$ & 0.06 & $7.46^{* * *}$ & 1998 \\
\hline UK & -2.34 & -1.66 & $0.13 *$ & -3.17 & 1979 & $-2.82 *$ & $-3.79 * * *$ & 0.19 & $5.23 * * *$ & 2001 \\
\hline USA & -3.01 & -2.62 & $0.15^{* *}$ & -3.56 & 1992 & $-4.29^{* * *}$ & $-3.74^{* * *}$ & 0.07 & $-6.29 * * *$ & 2008 \\
\hline Venezuela & -2.19 & -1.24 & $0.21^{* *}$ & -3.81 & 1982 & $-5.03^{* * *}$ & $-4.80^{* * *}$ & 0.27 & $-5.73^{* * *}$ & 2009 \\
\hline Vietnam & -2.09 & -2.3 & $0.15^{* *}$ & - & - & $-2.66 *$ & $-2.72 *$ & 0.31 & - & - \\
\hline
\end{tabular}

Notes: ${ }^{*}{ }^{* *}$ and ${ }^{* * *}$ denotes significant at 10\%, 5\% and 1\% respectively. ADF-Augmented Dickey-Fuller Test, PP-Phillips-Perron Test, and KPSS-Kwiatkowski-Phillips-Schmidt-Shin Test. 
Table A2. Unit root rest-real energy consumption per capita.

\begin{tabular}{|c|c|c|c|c|c|c|c|c|c|c|}
\hline \multirow{2}{*}{ Countries } & \multicolumn{5}{|c|}{ Level } & \multicolumn{5}{|c|}{ First Difference } \\
\hline & ADF & PP & KPSS & Breakpoint & Break & ADF & $\mathbf{P P}$ & KPSS & Breakpoint & Break \\
\hline Albania & -1.27 & -1.50 & $0.15^{* *}$ & -2.29 & 1989 & $-6.18^{* * *}$ & $-6.20^{* * *}$ & 0.14 & $-7.65^{* * *}$ & 1992 \\
\hline Algeria & -2.94 & -2.92 & $0.16^{* *}$ & -4.08 & 2002 & $-4.29 * * *$ & $-5.07^{* * *}$ & 0.25 & $-7.55^{* * *}$ & 1982 \\
\hline Australia & -1.43 & -1.29 & $0.21^{* *}$ & -4.12 & 1993 & $-7.65^{* * *}$ & $-7.61^{* * *}$ & 0.31 & $-8.67 * * *$ & 2007 \\
\hline Austria & -1.83 & -1.83 & $0.21^{* *}$ & -3.06 & 1,995 & $-6.72 * * *$ & $-6.74^{* * *}$ & 0.31 & $-8.11^{* * *}$ & 1972 \\
\hline Bangladesh & -0.93 & -0.62 & $0.20 * *$ & -0.69 & 2000 & $-8.18^{* * *}$ & $-8.18^{* * *}$ & 0.28 & $-9.16^{* * *}$ & 2001 \\
\hline Belgium & -1.61 & -1.62 & $0.19^{* *}$ & -3.53 & 2012 & $-6.61^{* * *}$ & $-6.61^{* * *}$ & 0.32 & $-7.29 * * *$ & 1972 \\
\hline Bolivia & -2.74 & -2.82 & $0.16^{* *}$ & -2.61 & 1993 & $-7.74^{* * *}$ & $-7.63^{* * *}$ & 0.11 & $-8.36^{* * *}$ & 2001 \\
\hline Brazil & -1.61 & -2.06 & $0.15^{* *}$ & -2.54 & 2003 & $-5.59 * * *$ & $-5.59 * * *$ & 0.13 & $-6.51^{* * *}$ & 1981 \\
\hline Canada & -2.13 & -2.11 & $0.22 * * *$ & - & - & $-4.77^{* * *}$ & $-4.57^{* * *}$ & $0.35 *$ & - & - \\
\hline Chile & -3.02 & -2.66 & $0.15^{* *}$ & -3.34 & 1987 & $-4.52 * * *$ & $-4.48^{* * *}$ & 0.27 & $-5.58^{* * *}$ & 1975 \\
\hline China & -1.35 & -0.88 & $0.19^{* *}$ & -3.28 & 2002 & $-3.57^{* *}$ & $-3.57 * *$ & 0.31 & $-4.49 * *$ & 2001 \\
\hline Colombia & -1.76 & -1.86 & $0.17^{* *}$ & -1.97 & 1984 & $-7.17^{* * *}$ & $-7.14^{* * *}$ & 0.09 & $-8.18^{* * *}$ & 1999 \\
\hline $\begin{array}{l}\text { The Czech } \\
\text { Republic }\end{array}$ & -2.17 & -2.27 & $0.18^{* *}$ & -3.45 & 1990 & $-7.12^{* * *}$ & $-7.12^{* * *}$ & 0.08 & $-7.45^{* * *}$ & 1999 \\
\hline Denmark & -2.96 & -2.97 & $0.20^{* *}$ & -3.57 & 2009 & $-7.18^{* * *}$ & $-7.14^{* * *}$ & 0.09 & $-8.18^{* * *}$ & 1999 \\
\hline Ecuador & -2.78 & -2.72 & $0.15^{* *}$ & -3.07 & 1995 & $-7.32^{* * *}$ & $-7.45^{* * *}$ & 0.15 & $-7.81^{* * *}$ & 1985 \\
\hline Egypt & -1.09 & -1.18 & $0.15^{* *}$ & -2.73 & 2001 & $-5.58 * * *$ & $-5.17^{* * *}$ & $0.37^{*}$ & $-6.42^{* * *}$ & 1985 \\
\hline Finland & -1.35 & -1.07 & $0.23^{* * *}$ & - & - & $-7.27^{* * *}$ & $-7.33^{* * *}$ & 0.28 & - & - \\
\hline France & -1.46 & -1.45 & $0.23^{* * *}$ & - & - & $-6.15^{* * *}$ & $-6.14^{* * *}$ & 0.29 & - & - \\
\hline Gabon & -1.07 & -1.08 & $0.19^{* *}$ & -2.23 & 2001 & $-5.99 * * *$ & $-6.00^{* * *}$ & 0.21 & $-6.61^{* * *}$ & 1976 \\
\hline Germany & -1.96 & -1.96 & $0.23^{* * *}$ & -3.28 & 2008 & $-5.86^{* * *}$ & $-5.82 * * *$ & 0.27 & $-11.34^{* * *}$ & 1972 \\
\hline Hungary & -1.97 & -1.97 & $0.21 * *$ & -3.56 & 2008 & $-4.68^{* * *}$ & $-4.66^{* * *}$ & 0.18 & $-6.83 * * *$ & 1973 \\
\hline India & -0.21 & -0.38 & $0.18^{* *}$ & -0.49 & 2005 & $-4.81^{* * *}$ & $-5.04^{* * *}$ & 0.17 & $-7.19 * * *$ & 2003 \\
\hline Indonesia & -1.24 & -1.24 & $0.15^{* *}$ & -3.16 & 1999 & $-6.58^{* * *}$ & $-6.58^{* * *}$ & 0.19 & $-8.50 * * *$ & 1990 \\
\hline Iran & -3.33 & -3.25 & $0.16^{* *}$ & -3.59 & 1988 & $-8.34^{* * *}$ & $-8.16^{* * *}$ & 0.15 & $-10.28^{* * *}$ & 1977 \\
\hline Italy & -3.11 & -3.12 & $0.20 * *$ & -2.26 & 1995 & $-6.29 * * *$ & $-6.35^{* * *}$ & 0.27 & $-7.99 * * *$ & 2007 \\
\hline Japan & -2.78 & -2.52 & $0.21^{* *}$ & -2.61 & 2008 & $-5.85^{* * *}$ & $-5.85^{* * *}$ & 0.32 & $-7.36^{* * *}$ & 1972 \\
\hline Korea South & -0.19 & -0.17 & $0.21^{* *}$ & -2.65 & 1985 & $-5.34 * * *$ & $-5.42 * * *$ & 0.28 & $7.64^{* * *}$ & 1998 \\
\hline The Netherlands & -2.29 & -2.27 & $0.19^{* *}$ & - & - & $-5.83^{* * *}$ & $-5.84^{* * *}$ & 0.32 & - & - \\
\hline New Zealand & -2.06 & -1.98 & $0.24^{* * *}$ & -3.59 & 1983 & $-7.37^{* * *}$ & $-7.37^{* * *}$ & 0.33 & $-8.368^{* * *}$ & 1979 \\
\hline Nigeria & -2.63 & -2.46 & $0.18^{* *}$ & -3.04 & 1998 & $-5.51^{* * *}$ & $-5.44^{* * *}$ & 0.24 & $-6.42^{* * *}$ & 1994 \\
\hline Norway & -1.97 & -1.73 & $0.25^{* * *}$ & - & - & $-9.44^{* * *}$ & $-9.91 * * *$ & $0.36 *$ & - & - \\
\hline Pakistan & -1.87 & -1.88 & $0.18^{* *}$ & -3.21 & 1986 & $-5.16^{* * *}$ & $-5.18^{* * *}$ & 0.33 & $-7.33^{* * *}$ & 2007 \\
\hline Philippines & -2.49 & -2.53 & $0.15^{* *}$ & -3.11 & 1985 & $-8.63^{* * *}$ & $-8.33^{* * *}$ & 0.09 & $-8.97 * * *$ & 2009 \\
\hline Portugal & -0.16 & -0.16 & $0.22 * * *$ & - & - & $-5.41^{* * *}$ & $-5.44^{* * *}$ & 0.26 & - & - \\
\hline South Africa & -1.98 & -1.95 & $0.16^{* *}$ & -2.61 & 2002 & $-6.22 * * *$ & $-6.23^{* * *}$ & 0.16 & $-6.87^{* * *}$ & 2007 \\
\hline Spain & -0.75 & -0.91 & $0.22 * * *$ & - & - & $-4.31^{* * *}$ & $-4.39^{* * *}$ & 0.26 & - & - \\
\hline Sri Lanka & -2.28 & -2.08 & $0.18^{* *}$ & -2.99 & 1994 & $-7.32^{* * *}$ & $-7.45^{* * *}$ & 0.21 & $-8.18^{* * *}$ & 1996 \\
\hline Sudan & -2.97 & -2.85 & $0.17^{* *}$ & -3.24 & 1985 & $-7.01^{* * *}$ & $-11.08^{* * *}$ & 0.29 & $-10.18^{* * *}$ & 2002 \\
\hline Sweden & -2.13 & -2.13 & $0.25^{* * *}$ & -3.45 & 2008 & $-8.37^{* * *}$ & $-8.45^{* * *}$ & 0.31 & $-9.15^{* * *}$ & 1985 \\
\hline Syrian & -0.26 & -0.51 & $0.21^{* *}$ & -1.98 & 2004 & $-5.49^{* * *}$ & $-5.55^{* * *}$ & $0.35 *$ & $-6.75^{* * *}$ & 2005 \\
\hline Thailand & -1.91 & -2.01 & $0.19^{* *}$ & -3.24 & 1986 & $-4.88^{* * *}$ & $4.98^{* * *}$ & 0.09 & $-6.21^{* * *}$ & 1983 \\
\hline $\begin{array}{c}\text { Trinidad and } \\
\text { Tobago }\end{array}$ & -2.19 & -2.21 & $0.19^{* *}$ & -2.35 & 1995 & $-3.47^{* *}$ & $-6.33^{* * *}$ & 0.15 & $-7.38^{* * *}$ & 1978 \\
\hline Turkey & -2.52 & -2.57 & $0.17^{* *}$ & -1.79 & 2002 & $-6.42^{* * *}$ & $-6.42^{* * *}$ & 0.09 & $-7.35^{* * *}$ & 1999 \\
\hline UAE & -0.89 & -0.83 & $0.21^{* *}$ & -2.63 & 2003 & $-6.39 * * *$ & $-6.42^{* * *}$ & 0.19 & $-7.99^{* * *}$ & 1987 \\
\hline UK & -0.54 & -0.35 & $0.19^{* *}$ & -2.92 & 2008 & $-7.27^{* * *}$ & $-7.24^{* * *}$ & 0.13 & $-8.57^{* * *}$ & 2005 \\
\hline USA & -2.62 & -1.92 & $0.19^{* *}$ & -4.07 & 2008 & $-5.05^{* * *}$ & $-4.94^{* * *}$ & 0.29 & $-5.56^{* * *}$ & 1978 \\
\hline Venezuela & -2.92 & -2.97 & $0.15^{* *}$ & -3.57 & 2004 & $-10.98^{* * *}$ & $-10.46^{* * *}$ & 0.31 & $-13.16^{* * *}$ & 1991 \\
\hline Vietnam & -1.74 & -1.75 & $0.22 * * *$ & -1.96 & 1996 & $-5.32 * * *$ & $-5.51^{* * *}$ & 0.32 & $7.43^{* * *}$ & 1992 \\
\hline
\end{tabular}

Notes: ${ }^{*}$ ** and ${ }^{* * *}$ denotes significant at $10 \%, 5 \%$ and $1 \%$ respectively. ADF-Augmented Dickey-Fuller Test, PP-Phillips-Perron Test, and KPSS-Kwiatkowski-Phillips-Schmidt-Shin Test. 
Table A3. Unit root test-income volatility.

\begin{tabular}{|c|c|c|c|c|c|c|}
\hline Countries & Model & ADF & PP & KPSS & Breakpoint & Break \\
\hline Albania & EGARCH(1,1) & $-3.77^{* *}$ & $-3.57 * *$ & 0.07 & $-7.64^{* * *}$ & 2002 \\
\hline Algeria & EGARCH(1,1) & $-4.51^{* * *}$ & $-5.80^{* * *}$ & 0.07 & $-5.20^{* * *}$ & 1992 \\
\hline Australia & EGARCH $(3,0)$ & $-6.74^{* * *}$ & $-8.08^{* * *}$ & 0.19 & $-12.26^{* * *}$ & 2010 \\
\hline Austria & EGARCH $(1,0)$ & $-5.14^{* * *}$ & $-5.15^{* * *}$ & 0.1 & $-23.59^{* * *}$ & 1985,1990 \\
\hline Bangladesh & EGARCH(1,2) & $-7.47^{* * *}$ & $-5.56^{* * *}$ & 0.08 & $-9.71^{* * *}$ & 2001 \\
\hline Belgium & EGARCH $(1,0)$ & $-4.59^{* * *}$ & $-4.65^{* * *}$ & 0.06 & $-6.01^{* * *}$ & 2004 \\
\hline Bolivia & EGARCH $(1,0)$ & $-4.81^{* * *}$ & $-4.48^{* * *}$ & 0.1 & $-5.09 * * *$ & 1976 \\
\hline Brazil & EGARCH(2,1) & $-3.11^{* *}$ & $-4.04^{* * *}$ & 0.1 & $-4.45^{* *}$ & 1994 \\
\hline Canada & EGARCH(1.0) & $-5.37^{* * *}$ & $-5.22^{* * *}$ & 0.15 & $-10.46^{* * *}$ & 1995 \\
\hline Chile & EGARCH(2,2) & $-2.97^{* *}$ & $-2.92^{* *}$ & 0.11 & $-5.06^{* * *}$ & 2001 \\
\hline China & EGARCH(2,2) & $-5.71^{* * *}$ & $-5.53^{* * *}$ & 0.14 & $-13.30^{* * *}$ & 1992,1999 \\
\hline Colombia & EGARCH $(1,0)$ & $-5.76^{* * *}$ & $-5.77^{* * *}$ & 0.17 & $-14.09 * * *$ & 1994,1997 \\
\hline The Czech Republic & EGARCH(1,2) & $-3.72 * * *$ & $-3.81^{* * *}$ & 0.22 & - & - \\
\hline Denmark & EGARCH(2,2) & $-6.74^{* * *}$ & $-8.11^{* * *}$ & 0.12 & $-8.44^{* * *}$ & 2004 \\
\hline Ecuador & EGARCH(2,2) & $-4.92^{* * *}$ & $-5.42^{* * *}$ & 0.21 & $-4.64^{* *}$ & 1982,1990 \\
\hline Egypt & EGARCH $(3,0)$ & $-5.23^{* * *}$ & $-5.13^{* * *}$ & 0.09 & $-7.07^{* * *}$ & 1996 \\
\hline Finland & EGARCH $(1,1)$ & $-8.84^{* * *}$ & $-8.77^{* * *}$ & 0.17 & $-10.96^{* * *}$ & 1985,1991 \\
\hline France & EGARCH(1,0) & $-6.67^{* * *}$ & $-6.66^{* * *}$ & 0.31 & $-8.92^{* * *}$ & 1991,2010 \\
\hline Gabon & EGARCH(1,1) & $-12.53^{* * *}$ & $-11.76^{* * *}$ & 0.08 & $-14.89^{* * *}$ & $\begin{array}{c}1987,1997 \\
2003\end{array}$ \\
\hline Germany & EGARCH(2,2) & $-4.09 * * *$ & $-3.17^{* *}$ & 0.21 & $-4.49 * *$ & 1994 \\
\hline Hungary & EGARCH(2,2) & $10.31^{* * *}$ & $-9.74^{* * *}$ & 0.35 * & $-14.61^{* * *}$ & 1978 \\
\hline India & EGARCH(1,2) & $-6.56^{* * *}$ & $-7.92^{* * *}$ & 0.28 & $-6.95^{* * *}$ & 1975,1981 \\
\hline Indonesia & EGARCH $(1,1)$ & $-2.93^{* *}$ & $3.87^{* * *}$ & 0.14 & $-5.45^{* * *}$ & 1983,1992 \\
\hline Iran & EGARCH(1,1) & $-3.04^{* *}$ & $-3.19^{* *}$ & 0.23 & $-11.73^{* * *}$ & 1975,1978 \\
\hline Italy & EGARCH $(1,0)$ & $-5.83^{* * *}$ & $-5.72^{* * *}$ & 0.28 & $-6.29 * * *$ & 1988 \\
\hline Japan & EGARCH $(1,1)$ & $-6.73^{* * *}$ & $-6.38^{* * *}$ & 0.1 & $7.26^{* * *}$ & 2008 \\
\hline Korea South & EGARCH $(1,0)$ & $-6.62^{* * *}$ & $-6.62^{* * *}$ & 0.13 & $-6.91^{* * *}$ & 1987,2010 \\
\hline The Netherlands & EGARCH(2,0) & $-7.84^{* * *}$ & $11.11^{* * *}$ & 0.14 & $-11.09 * * *$ & 1989,1992 \\
\hline New Zealand & EGARCH(2,2) & $3.02 * *$ & $-3.07^{* *}$ & 0.14 & $-5.67^{* * *}$ & 1981 \\
\hline Nigeria & EGARCH(2,2) & $-3.99 * * *$ & $-10.23^{* * *}$ & 0.11 & $-11.53^{* * *}$ & 1980 \\
\hline Norway & EGARCH $(1,3)$ & $-7.79^{* * *}$ & $-8.88^{* * *}$ & 0.22 & - & - \\
\hline Pakistan & EGARCH $(1,0)$ & $-4.39 * * *$ & $-4.38^{* * *}$ & 0.11 & $-4.78^{* * *}$ & 2004 \\
\hline Philippines & EGARCH $(1,0)$ & $-6.22^{* * *}$ & $-6.36^{* * *}$ & 0.16 & $-7.01^{* * *}$ & 1986, 2004 \\
\hline Portugal & EGARCH(2,2) & $-11.18^{* * *}$ & $-10.89 * * *$ & 0.08 & $-13.18^{* * *}$ & 1979 \\
\hline South Africa & EGARCH(1,1) & $-3.09^{* *}$ & $-3.14^{* *}$ & 0.34 & $-4.51^{* *}$ & 2002 \\
\hline Spain & EGARCH(2,2) & $-8.99 * * *$ & $-5.92^{* * *}$ & 0.28 & $-10.33^{* * *}$ & 1999 \\
\hline Sri Lanka & EGARCH(2,2) & $-7.81^{* * *}$ & $-7.19^{* * *}$ & 0.18 & $-14.58^{* * *}$ & 1978 \\
\hline Sudan & EGARCH $(3,0)$ & $-7.92^{* * *}$ & $-10.49 * * *$ & 0.24 & $-9.47^{* * *}$ & 2000 \\
\hline Sweden & EGARCH $(1,0)$ & $-6.07^{* * *}$ & $-6.08^{* * *}$ & 0.19 & $-6.91^{* * *}$ & 2004 \\
\hline Syrian & EGARCH $(1,0)$ & $-6.55^{* * *}$ & $-6.54^{* * *}$ & 0.14 & $-33.61^{* * *}$ & 1975 \\
\hline Thailand & EGARCH $(1,0)$ & $-7.55^{* * *}$ & $-7.61^{* * *}$ & 0.19 & $-8.28^{* * *}$ & 1985 \\
\hline Trinidad and Tobago & EGARCH(1,1) & $-2.65 *$ & $-2.92^{* * *}$ & 0.18 & $-4.96^{* * *}$ & 1982 \\
\hline Turkey & EGARCH $(2,0)$ & $-3.75^{* * *}$ & $-3.75^{* * *}$ & 0.26 & $-4.73^{* * *}$ & 1978 \\
\hline UAE & EGARCH $(1,0)$ & $-4.84^{* * *}$ & $-4.80^{* * *}$ & 0.21 & $-12.85^{* * *}$ & 1999 \\
\hline UK & EGARCH $(1,0)$ & $-5.94^{* * *}$ & $-5.95^{* * *}$ & 0.12 & $-6.35^{* * *}$ & 1995 \\
\hline USA & EGARCH(2,1) & $-3.11^{* *}$ & $-3.22 * *$ & $0.41 *$ & $-5.27^{* * *}$ & 1975 \\
\hline Venezuela & EGARCH(2,0) & $-4.73^{* * *}$ & $-3.24^{* *}$ & 0.09 & $-5.34^{* * *}$ & 1983 \\
\hline Vietnam & EGARCH(2,2) & $-14.41^{* * *}$ & $-13.36^{* * *}$ & 0.34 & $-54.22 * * *$ & 1997 \\
\hline
\end{tabular}

Notes: ${ }^{*}{ }^{* *}$ and ${ }^{* * *}$ denotes significant at 10\%, 5\% and 1\% respectively. ADF-Augmented Dickey-Fuller Test, PP-Phillips-Perron Test, and KPSS-Kwiatkowski-Phillips-Schmidt-Shin Test. 
Table A4. Unit root test—energy consumption volatility.

\begin{tabular}{|c|c|c|c|c|c|c|}
\hline Countries & Model & ADF & PP & KPSS & Breakpoint & Break \\
\hline Albania & EGARCH(1,1) & $-8.26^{* * *}$ & $-8.43^{* * *}$ & 0.21 & $-14.68 * * *$ & 1992 \\
\hline Algeria & EGARCH(1,1) & $-4.08^{* * *}$ & $-2.53^{* *}$ & 0.31 & $7.56^{* * *}$ & 1995 \\
\hline Australia & EGARCH $(1,0)$ & $-6.99^{* * *}$ & $-6.98^{* * *}$ & 0.08 & $-7.57^{* * *}$ & 2011 \\
\hline Austria & EGARCH(1,1) & $-3.60^{* *}$ & $-3.55^{* *}$ & 0.23 & $-5.07^{* * *}$ & 2004 \\
\hline Bangladesh & EGARCH(1,1) & $-3.98^{* * *}$ & $-3.98^{* * *}$ & 0.09 & $-5.02 * * *$ & 2011 \\
\hline Belgium & EGARCH(1,1) & $-6.09^{* * *}$ & $-6.29 * * *$ & 0.24 & $-6.99 * * *$ & 1982 \\
\hline Bolivia & EGARCH $(1,0)$ & $-6.69^{* * *}$ & $-8.78^{* * *}$ & 0.27 & $7.07^{* * *}$ & 1999 \\
\hline Brazil & EGARCH $(3,0)$ & $-3.91^{* * *}$ & $-3.82^{* * *}$ & 0.15 & $-5.83^{* * *}$ & 1982 \\
\hline Canada & EGARCH(1,1) & $-3.65^{* * *}$ & $-3.69^{* * *}$ & 0.21 & $-5.13^{* * *}$ & 1981 \\
\hline Chile & EGARCH $(1,1)$ & $-9.72^{* * *}$ & $-9.75^{* * *}$ & 0.13 & $-11.29^{* * *}$ & 2012 \\
\hline China & EGARCH $(1,0)$ & $-5.99 * * *$ & $-5.85^{* * *}$ & 0.18 & $-7.21^{* * *}$ & 2004 \\
\hline Colombia & EGARCH $(4,0)$ & $-6.82^{* * *}$ & $-6.97^{* * *}$ & 0.11 & $-15.35^{* * *}$ & 1980 \\
\hline The Czech Republic & EGARCH(2,2) & $-9.99 * * *$ & $-12.01^{* * *}$ & 0.11 & $-11.97^{* * *}$ & 1993 \\
\hline Denmark & EGARCH(1,1) & $-4.76^{* * *}$ & $-4.79 * * *$ & 0.19 & $-5.74^{* * *}$ & 1996 \\
\hline Ecuador & EGARCH(2,2) & $-7.47^{* * *}$ & $-7.46^{* * *}$ & 0.17 & $-10.01^{* * *}$ & 2000 \\
\hline Egypt & EGARCH(2,2) & $-10.86^{* * *}$ & $10.24^{* * *}$ & 0.25 & $-11.91^{* * *}$ & 1985 \\
\hline Finland & EGARCH(2,1) & $-10.15^{* * *}$ & $-10.16^{* * *}$ & 0.09 & $-10.21^{* * *}$ & 1987 \\
\hline France & EGARCH(1,1) & $-4.28^{* * *}$ & $-4.31^{* * *}$ & 0.16 & $-5.68^{* * *}$ & 1978 \\
\hline Gabon & EGARCH(2,1) & $-7.88^{* * *}$ & $-8.08^{* * *}$ & 0.19 & $-14.26^{* * *}$ & 1975 \\
\hline Germany & EGARCH $(3,0)$ & $-6.64^{* * *}$ & $-6.64^{* * *}$ & 0.29 & $-46.67^{* * *}$ & 1974 \\
\hline Hungary & EGARCH(2,0) & $-4.46^{* * *}$ & $-4.47^{* * *}$ & 0.12 & $-5.16^{* * *}$ & 1993 \\
\hline India & EGARCH(2,2) & $-6.62^{* * *}$ & $-8.05^{* * *}$ & 0.15 & $-8.11^{* * *}$ & 2010 \\
\hline Indonesia & EGARCH(1,1) & $-3.22 * *$ & $-3.15^{* *}$ & 0.28 & $-5.63^{* * *}$ & 1993 \\
\hline Iran & EGARCH(1,0) & $-6.61^{* * *}$ & $-6.61^{* * *}$ & 0.26 & $-11.24^{* * *}$ & 1984 \\
\hline Italy & EGARCH $(1,1)$ & $-2.68 *$ & $-2.69 *$ & 0.21 & $-4.92^{* * *}$ & 2009 \\
\hline Japan & EGARCH(1,1) & $-7.25^{* * *}$ & $-7.34^{* * *}$ & 0.32 & $7.61^{* * *}$ & 2008 \\
\hline Korea South & EGARCH $(1,1)$ & $-3.59^{* * *}$ & $-3.56^{* *}$ & 0.11 & $4.96^{* *}$ & 1998 \\
\hline The Netherlands & EGARCH(2,2) & $-6.09^{* * *}$ & $-6.09 * * *$ & 0.18 & $-6.80^{* * *}$ & 2011 \\
\hline New Zealand & EGARCH(2,2) & $-7.18^{* * *}$ & $-7.64^{* * *}$ & 0.32 & $-7.61^{* * *}$ & 1981 \\
\hline Nigeria & EGARCH(1,2) & $-7.21^{* * *}$ & $-7.18^{* * *}$ & 0.28 & $-8.29^{* * *}$ & 2010 \\
\hline Norway & EGARCH(2,2) & $-6.20^{* * *}$ & $-9.74^{* * *}$ & 0.15 & $-7.21^{* * *}$ & 1999 \\
\hline Pakistan & EGARCH $(1,0)$ & $-6.22^{* * *}$ & $6.23 * * *$ & 0.29 & $-7.45^{* * *}$ & 2009 \\
\hline Philippines & EGARCH $(1,0)$ & $-11.42^{* * *}$ & $-11.21^{* * *}$ & 0.3 & $-13.10^{* * *}$ & 1984 \\
\hline Portugal & EGARCH(1,1) & $-3.84^{* * *}$ & $-3.84^{* * *}$ & 0.11 & $-4.57^{* *}$ & 1989 \\
\hline South Africa & EGARCH(1,1) & $-3.31^{* *}$ & $-3.23^{* *}$ & 0.14 & - & - \\
\hline Spain & EGARCH $(1,2)$ & $-7.46^{* * *}$ & $-7.42^{* * *}$ & 0.24 & $-12.17^{* * *}$ & 1974 \\
\hline Sri Lanka & EGARCH(1,2) & $-7.49^{* * *}$ & $-7.43^{* * *}$ & 0.18 & $-8.87^{* * *}$ & 1997 \\
\hline Sudan & EGARCH(2,1) & $-7.63^{* * *}$ & $-7.78^{* * *}$ & 0.18 & $-9.44^{* * *}$ & 2000 \\
\hline Sweden & EGARCH(1,1) & $-9.61^{* * * *}$ & $-10.64^{* * * *}$ & 0.25 & $-10.21^{* * *}$ & 2010 \\
\hline Syrian & EGARCH $(1,0)$ & $-5.16^{* * *}$ & $-5.18^{* * *}$ & 0.23 & $-6.21^{* * *}$ & 2011 \\
\hline Thailand & EGARCH(2,2) & $-6.54^{* * *}$ & $-6.54^{* * *}$ & 0.09 & $-8.14^{* * *}$ & 1985 \\
\hline Trinidad and Tobago & EGARCH $(1,1)$ & $-15.05^{* * *}$ & $-12.96^{* * *}$ & 0.28 & $-17.45^{* * *}$ & 1999 \\
\hline Turkey & EGARCH $(1,1)$ & $-7.33^{* * *}$ & $-14.77^{* * *}$ & 0.21 & $-7.92^{* * *}$ & 2006 \\
\hline UAE & EGARCH $(3,0)$ & $-6.43^{* * *}$ & $-6.56^{* * *}$ & 0.29 & $-9.22^{* * *}$ & 1999 \\
\hline UK & EGARCH(1,2) & $-7.13^{* * *}$ & $-7.12^{* * *}$ & 0.12 & $-7.65^{* * *}$ & 2005 \\
\hline USA & EGARCH $(2,0)$ & $-7.36^{* * *}$ & $-6.45^{* * *}$ & 0.31 & $-7.96^{* * *}$ & 1994 \\
\hline Venezuela & EGARCH(2,0) & $-14.15^{* * *}$ & $-14.52^{* * *}$ & 0.18 & $-14.94^{* * *}$ & 2002 \\
\hline Vietnam & EGARCH(2,2) & $-8.37^{* * *}$ & $-8.37^{* * *}$ & 0.12 & $-14.24^{* * *}$ & 1974 \\
\hline
\end{tabular}

Notes: ${ }^{*}, * *$ and ${ }^{* * *}$ denotes significant at $10 \%, 5 \%$ and $1 \%$ respectively. ADF-Augmented Dickey-Fuller Test, PP-Phillips-Perron Test, and KPSS-Kwiatkowski-Phillips-Schmidt-Shin Test. 
Table A5. Cointegration test.

\begin{tabular}{|c|c|c|c|c|c|c|c|c|}
\hline \multirow{2}{*}{ Countries } & \multicolumn{4}{|c|}{ Trace Test } & \multicolumn{4}{|c|}{ Max Eigen Value } \\
\hline & $\mathbf{r}=\mathbf{0}$ & $r=1$ & $\mathbf{r}=2$ & $r=3$ & $\mathbf{r}=\mathbf{0}$ & $r=1$ & $\mathbf{r}=2$ & $\mathbf{r}=3$ \\
\hline Albania & $103.58^{* * *}$ & $41.51^{* * *}$ & $12.53^{* *}$ & 1.46 & $62.08^{* * *}$ & $28.97^{* * *}$ & $11.22 * *$ & 1.46 \\
\hline Algeria & $103.48^{* * *}$ & $61.60^{* * *}$ & $26.52^{* *}$ & 0.19 & $41.88^{* * *}$ & $25.82 * * *$ & 12.94 & 0.19 \\
\hline Australia & $67.73^{* * *}$ & $37.05^{* *}$ & 14.35 * & 1.41 & $13.68^{* *}$ & $22.69 * *$ & 6.23 & 1.41 \\
\hline Austria & $182.32 * * *$ & $27.38^{* *}$ & 11.97 * & 0.16 & $154.95^{* * *}$ & $15.41 *$ & $11.80^{* *}$ & 0.164 \\
\hline Bangladesh & $87.21^{* * *}$ & $40.31^{* * *}$ & 11.71 * & 0.91 & $46.91^{* * *}$ & $17.79 * *$ & $11.22 *$ & 0.91 \\
\hline Belgium & $75.43^{* * *}$ & $43.14^{* *}$ & 22.91 & 4.13 & $32.29 * * *$ & $20.24^{* *}$ & $18.77^{* * *}$ & 4.13 \\
\hline Bolivia & $64.39 * * *$ & $27.89 *$ & 6.71 & 0.61 & $36.49 * * *$ & $21.19 * *$ & 6.1 & 0.61 \\
\hline Brazil & $52.38 * * *$ & $28.89 * *$ & $12.31 *$ & 2.49 & $23.48 *$ & $16.58 *$ & $9.82 *$ & 2.49 \\
\hline Canada & $89.61^{* * *}$ & $48.51^{* *}$ & 24.96 * & 4.71 & $41.09 * * *$ & $23.55^{* *}$ & $20.25^{* *}$ & 4.71 \\
\hline Chile & $66.41^{* * *}$ & $35.06^{* *}$ & 14.40 * & 0.39 & $31.35^{* *}$ & $20.67 *$ & $14.01 *$ & 0.39 \\
\hline China & $117.78^{* * *}$ & $34.91^{* *}$ & $13.36^{* *}$ & 0.39 & $82.89^{* * *}$ & $21.54^{* *}$ & $12.97 * *$ & 0.39 \\
\hline Colombia & $71.78^{* * *}$ & $38.61^{* * *}$ & $17.46^{* *}$ & 2.69 & $33.17 * * *$ & $21.15^{* * *}$ & $14.77^{* *}$ & 2.69 \\
\hline The Czech Republic & $73.89^{* * *}$ & $33.44^{* * *}$ & 9.49 & 2.24 & $40.46^{* * *}$ & $23.95^{* * *}$ & 7.25 & 2.24 \\
\hline Denmark & $59.77^{* * *}$ & $23.51 *$ & $12.79 * *$ & 1.06 & $36.26^{* * *}$ & 10.71 & $11.73^{* *}$ & 1.06 \\
\hline Ecuador & $69.52 * * *$ & $27.47 *$ & 6.52 & 0.94 & $42.05^{* * *}$ & $20.95 *$ & 5.58 & 0.94 \\
\hline Egypt & $74.63^{* * *}$ & $41.39 * * *$ & $19.97^{* * *}$ & 1.04 & $33.23^{* * *}$ & $21.42 * *$ & $18.93^{* * *}$ & 1.04 \\
\hline Finland & $82.31^{* * *}$ & $40.09 * * *$ & $13.85 *$ & 1.91 & $42.22 * * *$ & $26.24 * * *$ & 12.56 & 1.29 \\
\hline France & $58.54 * * *$ & $33.34^{* * *}$ & 11.41 * & 0.43 & $25.21^{* *}$ & $21.94^{* *}$ & $11.22 *$ & 0.43 \\
\hline Gabon & $85.55^{* * *}$ & $34.71^{* *}$ & 8.41 & 2.15 & $50.84^{* * *}$ & $26.29 * * *$ & 6.26 & 2.15 \\
\hline Germany & $89.73^{* * *}$ & $43.08^{* * *}$ & $18.26^{* *}$ & 1.42 & $46.65^{* * *}$ & $24.81^{* *}$ & $16.83^{* *}$ & 1.42 \\
\hline Hungary & $60.64^{* * *}$ & $29.63 *$ & 10.97 & 0.66 & $31.01^{* *}$ & $18.66 *$ & 10.31 & 0.66 \\
\hline India & $161.61^{* * *}$ & $66.76^{* * *}$ & $27.42 * * *$ & 1.37 & $94.84 * * *$ & $39.34 * * *$ & $26.06^{* * *}$ & 1.37 \\
\hline Indonesia & $102.22 * * *$ & $36.26^{* * *}$ & 5.79 & 1.48 & $65.86^{* * *}$ & $30.57 * * *$ & 4.31 & 1.48 \\
\hline Iran & $165.52 * * *$ & $71.52 * * *$ & $30.64^{* * *}$ & 0.03 & $93.99 * * *$ & $40.87^{* * *}$ & $30.62 * * *$ & 0.03 \\
\hline Italy & $77.78^{* * *}$ & $37.66^{* * *}$ & $13.97 *$ & 1.7 & $40.11^{* * *}$ & $23.69 * *$ & 12.26 * & 1.7 \\
\hline Japan & $84.13^{* * *}$ & $46.64^{* * *}$ & $18.18^{* *}$ & 2.03 & $37.49^{* * *}$ & $28.46^{* * *}$ & $16.15^{* *}$ & 2.03 \\
\hline Korea South & $115.84^{* * *}$ & $69.29 * * *$ & $26.67 * * *$ & 6.51 & $46.54^{* * *}$ & $42.63^{* * *}$ & $20.15^{* * *}$ & 6.51 \\
\hline The Netherlands & $78.76^{* * *}$ & $35.74 * * *$ & $15.21 *$ & 2.41 & $43.01^{* * *}$ & $20.54 *$ & $12.79 *$ & 2.41 \\
\hline New Zealand & $86.91^{* * *}$ & $49.65^{* * *}$ & $20.38^{* *}$ & 5.53 & $37.26^{* * *}$ & $29.27 * * *$ & $14.82 *$ & 5.53 \\
\hline Nigeria & $75.61^{* * *}$ & $37.85^{* * *}$ & 9.02 & 0.01 & $37.75^{* * *}$ & $28.83^{* * *}$ & 9.01 & 0.01 \\
\hline Norway & $78.37^{* * *}$ & $40.93^{* *}$ & 14.62 & 6.12 & $37.43^{* * *}$ & $26.31^{* *}$ & 8.51 & 6.12 \\
\hline Pakistan & $54.76^{* * *}$ & $24.72 * *$ & 8.49 & 0.49 & $30.04^{* * *}$ & $16.23 *$ & 7.99 & 0.49 \\
\hline Philippines & $48.79 * * *$ & $25.03^{* *}$ & 4.45 & 0.05 & $23.76 *$ & $20.58^{* *}$ & 4.41 & 0.05 \\
\hline Portugal & $91.03^{* * *}$ & $48.25^{* * *}$ & 18.43 & 4.89 & $42.77^{* * *}$ & $29.83 * * *$ & 13.52 & 4.89 \\
\hline South Africa & $103.99^{* * *}$ & $44.73^{* *}$ & 21.32 & 7.26 & $59.27 * * *$ & $23.41 *$ & 14.06 & 7.26 \\
\hline Spain & - & - & - & - & - & - & - & - \\
\hline Sri Lanka & $77.29^{* * *}$ & $40.47^{* * *}$ & $17.23^{* *}$ & 0.14 & $36.81^{* * *}$ & $23.24 * *$ & $17.09 * *$ & 0.14 \\
\hline Sudan & $80.24^{* * *}$ & $43.67^{* * *}$ & 16.78 & 5.83 & $36.58 * * *$ & $26.89 * *$ & 11.05 & 5.73 \\
\hline Sweden & $74.98^{* * *}$ & $36.27^{* * *}$ & $16.18^{* *}$ & 2.31 & $38.10 * * *$ & $20.09 *$ & $13.87 *$ & 2.31 \\
\hline Syrian & $142.56^{* * *}$ & $32.12^{* *}$ & 10.36 & 1.94 & $110.45^{* * *}$ & $21.76^{* *}$ & 8.42 & 1.93 \\
\hline Thailand & $80.44^{* * *}$ & $41.07^{* * *}$ & $19.91 *$ & 3.17 & $39.37^{* * *}$ & $21.17 *$ & $16.74^{* *}$ & 3.17 \\
\hline Trinidad and Tobago & $75.74^{* * *}$ & $44.73^{* *}$ & 15.41 & 4.22 & $31.01 *$ & $29.32 * *$ & 11.18 & 4.22 \\
\hline Turkey & $94.45^{* * *}$ & $40.36^{* *}$ & $18.91 *$ & 3.02 & $54.09 * * *$ & $21.54 *$ & $15.88 *$ & 3.02 \\
\hline UAE & $94.05^{* * *}$ & $38.79^{* * *}$ & $16.36^{* *}$ & 2.45 & $55.25^{* *}$ & $22.44^{* *}$ & $13.91 *$ & 2.45 \\
\hline UK & $89.98^{* * *}$ & $36.93^{* * *}$ & $14.06 *$ & 0.78 & $53.05^{* * *}$ & $22.88^{* *}$ & $13.28 *$ & 0.78 \\
\hline USA & $79.53^{* * *}$ & $34.72^{* *}$ & $13.73 *$ & 0.01 & $44.81^{* * *}$ & $20.98 *$ & $13.72 *$ & 0.01 \\
\hline Venezuela & $75.08^{* * *}$ & $43.58^{* * *}$ & 16.87 & 4.16 & $31.51^{* *}$ & $26.71^{* *}$ & 12.71 & 4.16 \\
\hline Vietnam & $180.79 * * *$ & $71.44^{* * *}$ & $35.20^{* * *}$ & 0.49 & $109.35^{* * *}$ & $36.24^{* * *}$ & $34.71^{* * *}$ & 0.49 \\
\hline
\end{tabular}


Table A6. Short-run Granger causality results (F Statistic).

\begin{tabular}{|c|c|c|c|c|c|c|c|c|c|c|c|c|}
\hline Countries & $\begin{array}{l}\text { RGDPPC } \\
\rightarrow \text { ECPC }\end{array}$ & $\begin{array}{l}\text { INVOL } \\
\rightarrow \text { ECPC }\end{array}$ & $\begin{array}{c}\text { EVOL } \\
\rightarrow \text { ECPC }\end{array}$ & $\begin{array}{l}\text { ECPC } \rightarrow \\
\text { RGDPPC }\end{array}$ & $\begin{array}{l}\text { INVOL } \rightarrow \\
\text { RGDPPC }\end{array}$ & $\begin{array}{l}\text { EVOL } \rightarrow \\
\text { RGDPPC }\end{array}$ & $\begin{array}{l}\text { ECPC } \rightarrow \\
\text { INVOL }\end{array}$ & $\begin{array}{l}\text { RGDPPC } \\
\rightarrow \text { INVOL }\end{array}$ & $\begin{array}{l}\text { EVOL } \rightarrow \\
\text { INVOL }\end{array}$ & $\begin{array}{l}\text { ECPC } \rightarrow \\
\text { ECVOL }\end{array}$ & $\begin{array}{c}\text { RGDPPC } \\
\rightarrow \text { EVOL }\end{array}$ & $\begin{array}{l}\text { INVOL } \rightarrow \\
\text { EVOL }\end{array}$ \\
\hline Albania & $18.32 * * *$ & $19.15^{* * *}$ & 3.02 & $5.23 *$ & $7.48^{* *}$ & $7.78^{* *}$ & 0.19 & $28.18^{* * *}$ & $5.95^{* *}$ & $7.02 * *$ & $13.77^{* * *}$ & 2.79 \\
\hline Algeria & 1.99 & $5.71 * *$ & $12.97 * * *$ & 1.64 & $18.42^{* * *}$ & $4.74 *$ & 1.38 & $116.27^{* * *}$ & 0.59 & $11.76^{* * *}$ & 0.08 & 0.93 \\
\hline Austria & 0.1 & 0.02 & 0.78 & 1.2 & $12.21^{* * *}$ & $6.11^{* *}$ & 1.15 & $382.67^{* * *}$ & $8.16^{* *}$ & 0.11 & 0.22 & 0.16 \\
\hline Bangladesh & 0.05 & 0.96 & 4.35 & 0.17 & 0.42 & 0.02 & 1.68 & 1.71 & 0.52 & 1.97 & $5.32 *$ & 1.78 \\
\hline Belgium & $6.03^{* *}$ & $5.86^{* *}$ & 0.15 & 0.98 & 1.72 & 1.06 & 0.39 & $5.41 *$ & 0.86 & 3.43 & 0.75 & 0.89 \\
\hline Bolivia & $10.85^{* * *}$ & $5.81 *$ & 1.15 & 1.75 & 2.12 & 1.75 & 1.65 & 5.73 * & 1.86 & 1.17 & 0.24 & $9.51^{* * *}$ \\
\hline Canada & $9.29^{* *}$ & $7.89 * *$ & 3.27 & $16.87^{* * *}$ & $13.77^{* * *}$ & 3.57 & $7.25 * *$ & $20.27^{* * *}$ & 3.94 & 4.22 & $6.07 *$ & 3.72 \\
\hline Chile & 0.37 & $3.87 *$ & 1.63 & 0.85 & $16.75^{* * *}$ & $12.17^{* * *}$ & 0.86 & $29.36^{* * *}$ & 0.61 & 0.06 & 2.09 & 2.43 \\
\hline China & 0.67 & 0.77 & 0.26 & 0.19 & $13.85^{* * *}$ & 3.77 & $6.58 * *$ & $3.78 *$ & $5.05^{* *}$ & $36.06^{* * *}$ & 0.06 & 0.45 \\
\hline Colombia & 0.36 & $4.48 *$ & 1.68 & 1.05 & 0.27 & 2.75 & 1.62 & $53.96^{* * *}$ & 1.53 & 3.32 & 0.59 & 1.07 \\
\hline The Czech Republic & 1.86 & 0.77 & 0.53 & 0.93 & $7.68^{* * *}$ & $7.68^{* * *}$ & 1.85 & $6.79 *$ & 2.76 & $13.54^{* * *}$ & 4.65 & $11.72 * * *$ \\
\hline Denmark & 2.23 & $14.62^{* * *}$ & 4.89 & 4.22 & 3.21 & 7.13 & 3.04 & $7.65 *$ & 3.09 & 2.03 & 1.19 & $9.84 * *$ \\
\hline Ecuador & $6.95^{* *}$ & 4.23 * & $6.91 * *$ & 2.19 & 3.27 & 0.28 & 2.07 & $47.46^{* * *}$ & 2.66 & $6.68^{* *}$ & $8.14^{* *}$ & $9.19^{* *}$ \\
\hline Egypt & 2.72 & 0.74 & 4.82 & 4.43 & 3.34 & 4.42 & 0.11 & 3.19 & 0.43 & 3.24 & 2.01 & 3.16 \\
\hline Finland & 1.98 & 0.26 & $7.73^{* *}$ & 0.59 & 4.37 & 1.35 & 1.06 & $15.59^{* * *}$ & 0.32 & 0.82 & $12.78^{* * *}$ & 2.99 \\
\hline Gabon & $8.12^{* * *}$ & $10.88^{* * *}$ & 0.24 & $5.04 *$ & 0.29 & 2.01 & 0.43 & $33.18^{* * *}$ & 0.01 & 3.51 & 1.97 & 1.79 \\
\hline Germany & $11.11^{* *}$ & $7.72 *$ & $29.11^{* * *}$ & 4.09 & 5.03 & 4.09 & 4.96 & 4.13 & 4.25 & 7.12 & 1.05 & $8.86^{*}$ \\
\hline Hungary & $7.85 *$ & $10.33^{* *}$ & 5.22 & $17.04^{* * *}$ & 4.59 & $13.46^{* *}$ & $10.26^{*}$ & 5.52 & $12.05^{* *}$ & 3.95 & 2.54 & 4.36 \\
\hline India & $5.31 *$ & 2.62 & 3.3 & 1.41 & $12.53^{* * *}$ & 3.3 & 3.31 & 4.55 * & 2.41 & 2.08 & $9.09 * * *$ & $6.69^{* *}$ \\
\hline Indonesia & $7.73^{* * *}$ & $7.61^{* * *}$ & 0.28 & 1.65 & $3.38 *$ & 0.99 & $3.55^{* *}$ & $164.05^{* * *}$ & $7.32^{* * *}$ & 3.03 & 0.47 & 0.37 \\
\hline Iran & 2.97 * & $3.11 *$ & 0.02 & $22.06^{* * *}$ & $22.71^{* * *}$ & $5.13^{* *}$ & 0.51 & $55.22 * * *$ & 0.22 & $7.69^{* * *}$ & 2.45 & 1.26 \\
\hline Italy & 0.002 & 0.03 & 1.65 & 3.03 * & 0.01 & $3.74 *$ & $3.01 *$ & $24.15^{* * *}$ & 0.51 & 1.68 & 2.54 & 0.01 \\
\hline Japan & $33.66^{* * *}$ & $14.81^{* * *}$ & 1.46 & 2.44 & 0.24 & 0.15 & $5.27 *$ & 2.26 & $8.27^{* *}$ & 2.93 & 0.01 & 0.31 \\
\hline Korea, South & 3.18 & $8.15^{*}$ & 3.29 & $19.87^{* * *}$ & $13.34^{* *}$ & $14.26^{* *}$ & 3.02 & 3.9 & 3.33 & 3.97 & 0.92 & 3.15 \\
\hline The Netherlands & $6.59 * *$ & $4.97 *$ & $5.99 * *$ & 3.91 & 3.02 & 0.77 & 0.27 & $5.84 *$ & 1.03 & $8.38^{* *}$ & 1.63 & 0.32 \\
\hline New Zealand & 0.24 & 0.01 & 0.01 & 0.01 & $10.36^{* * *}$ & 0.78 & 0.4 & 0.35 & 0.65 & 0.08 & 2.14 & $5.54^{* *}$ \\
\hline Nigeria & 0.41 & $7.26^{* *}$ & $8.69^{* * *}$ & 2.96 & 0.51 & 0.41 & 3.61 & 3.63 & 3.05 & $6.77^{*}$ & $9.16^{* * *}$ & $7.01 * *$ \\
\hline Norway & 0.12 & 1.48 & 1.56 & 2.29 & 0.05 & $5.34 *$ & 0.81 & 0.39 & 3.68 & $5.28 *$ & 1.49 & $17.56^{* * *}$ \\
\hline Pakistan & $4.60 *$ & 0.59 & 0.16 & $4.54 *$ & 0.01 & 0.01 & 0.08 & 0.09 & $3.08 *$ & 0.21 & $3.67 *$ & $6.24^{* *}$ \\
\hline Philippines & 0.05 & $4.21^{* *}$ & 0.66 & $6.10^{* *}$ & $2.72 *$ & 0.11 & 2.22 & 1.15 & 0.13 & 0.76 & 0.54 & 1.69 \\
\hline Portugal & $11.52 * * *$ & $6.99 *$ & $9.59 * *$ & $9.65^{* *}$ & $10.63^{* *}$ & $12.15^{* * *}$ & 1.33 & $9.72 * *$ & 3.66 & $11.98^{* * *}$ & $13.34^{* * *}$ & $8.99 * *$ \\
\hline
\end{tabular}


Table A6. Cont.

\begin{tabular}{|c|c|c|c|c|c|c|c|c|c|c|c|c|}
\hline Countries & $\begin{array}{c}\text { RGDPPC } \\
\rightarrow \text { ECPC }\end{array}$ & $\begin{array}{l}\text { INVOL } \\
\rightarrow \text { ECPC }\end{array}$ & $\begin{array}{c}\text { EVOL } \\
\rightarrow \text { ECPC }\end{array}$ & $\begin{array}{l}\text { ECPC } \rightarrow \\
\text { RGDPPC }\end{array}$ & $\begin{array}{l}\text { INVOL } \rightarrow \\
\text { RGDPPC }\end{array}$ & $\begin{array}{l}\text { EVOL } \rightarrow \\
\text { RGDPPC }\end{array}$ & $\underset{\mathrm{INVOL}}{\mathrm{ECPC} \rightarrow}$ & $\begin{array}{l}\text { RGDPPC } \\
\rightarrow \text { INVOL }\end{array}$ & $\begin{array}{l}\text { EVOL } \rightarrow \\
\text { INVOL }\end{array}$ & $\begin{array}{l}\text { ECPC } \rightarrow \\
\text { ECVOL }\end{array}$ & $\begin{array}{c}\text { RGDPPC } \\
\rightarrow \text { EVOL }\end{array}$ & $\begin{array}{c}\text { INVOL } \rightarrow \\
\text { EVOL }\end{array}$ \\
\hline South Africa & 2.64 & $10.14^{* *}$ & 6.91 & $8.42 *$ & 1.87 & 2.27 & 2.05 & 0.38 & $8.37 *$ & 0.79 & 3.87 & 5.32 \\
\hline Spain & $11.88^{* *}$ & $13.23^{* *}$ & 2.47 & $8.61 *$ & $20.41^{* * *}$ & 3.08 & 8.69 * & $19.87^{* * *}$ & 4.03 & 6.27 & 3.55 & 3.17 \\
\hline Sudan & $3.48^{*}$ & 0.26 & 0.15 & 0.36 & 0.21 & 1.82 & 2.43 & 0.55 & $3.42 *$ & $3.78^{*}$ & 0.57 & $7.72 * * *$ \\
\hline Sweden & $3.71 *$ & 0.37 & 2.12 & 0.95 & 0.19 & 0.02 & 0.02 & 0.22 & 0.95 & 0.08 & 2.41 & 0.39 \\
\hline Syrian & $4.89 *$ & $4.89 *$ & $4.93 *$ & 2.71 & 0.16 & $5.43 *$ & 0.72 & $70.84^{* * *}$ & $4.92 *$ & $4.58 *$ & $4.91 *$ & $6.26^{* *}$ \\
\hline Thailand & $5.44 *$ & 1.18 & 2.82 & 1.41 & 1.52 & 3.95 & $5.44 *$ & $16.75^{* * *}$ & 0.19 & $10.04^{* * *}$ & 3.69 & $5.21 *$ \\
\hline Turkey & 1.49 & 0.91 & $2.91 *$ & 0.63 & $3.42 *$ & 0.22 & $9.21 * * *$ & $13.52 * * *$ & 0.49 & $35.43^{* * *}$ & 0.99 & 0.46 \\
\hline UAE & 0.72 & $6.48^{*}$ & $10.41^{* *}$ & 3.91 & 1.76 & 3.49 & $6.51 *$ & $95.00^{* * *}$ & 1.51 & 2.91 & 3.72 & 5.63 \\
\hline UK & 0.71 & $3.79 *$ & 0.02 & $2.99 *$ & 3.01 * & 1.15 & 1.72 & 1.72 & $12.31^{* * *}$ & $22.28^{* * *}$ & 1.95 & $8.98^{* * *}$ \\
\hline USA & 2.73 & $6.02 *$ & $6.42 *$ & $8.15^{* *}$ & 3.62 & 1.31 & 2.46 & 4.31 & 0.29 & 1.49 & $10.45^{* *}$ & $7.59 *$ \\
\hline Venezuela & $11.43^{* * *}$ & 3.73 & 2.46 & $19.97^{* * *}$ & 3.75 & $21.35^{* * *}$ & 1.83 & $13.11^{* * *}$ & 4.68 & 2.32 & 3.79 & 4.79 \\
\hline Vietnam & 0.87 & 0.09 & 0.38 & 7.52 ** & $31.26^{* * *}$ & 2.48 & 0.18 & $229.89 * * *$ & 0.49 & $13.67^{* * *}$ & $7.66^{* *}$ & 2.46 \\
\hline
\end{tabular}

Notes: ${ }^{*}, * *$ and ${ }^{* * *}$ denotes significant at $10 \%, 5 \%$ and $1 \%$ respectively. 


\section{Appendix B}

In the following, we present Yamamoto and Kurozumi procedures in line with our proposed VECM. To determine the long-run Granger non-causality from the $i^{\text {th }}$ component of $z_{t}$ to the $j$ th component of $z_{t}$, we define two $1 \times 4$ matrices, $R_{L}=\left[\begin{array}{llll}r_{1} & r_{2} & r_{3} & r_{4}\end{array}\right]$ and $R_{R}^{*}=$ $\left[\begin{array}{llll}r_{1}^{*} & r_{2}^{*} & r_{3}^{*} & r_{4}^{*}\end{array}\right]$, such that $r_{k}=\left\{\begin{array}{c}1 \text { if } k=j \\ 0 \text { otherwise }\end{array}\right.$ and $r_{k}^{*}=\left\{\begin{array}{c}1 \text { if } k=i \\ 0 \text { otherwise }\end{array}\right.$. For example, to test long-run Granger non-causality from ECPC to REGDPPC, corresponding restrictions may take the following form $R_{L}=\left[\begin{array}{llll}1 & 0 & 0 & 0\end{array}\right]$ and $R_{R}^{*}=\left[\begin{array}{llll}0 & 1 & 0 & 0\end{array}\right]$. Furthermore, long-run Granger non-causality from the $i$ th component of $z_{t}$ to the $j$ th component of $z_{t}$ is established by testing the null $H_{0}: R_{L} \bar{B} R_{R}^{\prime}=0$. We construct the Wald-type statistic using the generalised inverse $W^{-}=\operatorname{Tvec}\left(R_{L} \hat{\bar{B}} R_{R}^{\prime}\right) \prime\left(R_{L} \hat{C} \hat{\Sigma} \hat{C}^{\prime} R_{L}^{\prime} \otimes R_{R} \hat{P} \hat{\Sigma} \hat{P}^{\prime} R_{R}^{\prime}\right)^{-g} \operatorname{vec}\left(R_{L} \hat{\bar{B}} R_{R}^{\prime}\right) \stackrel{d}{\rightarrow} \chi_{s}^{2}$. where $T$ is the sample size, vec denotes the vectorisation of a matrix by constructing a column vector by appending each column of a matrix, and $\hat{\Sigma}$ is a consistent estimator of $\Sigma$, given by $\hat{\Sigma}=T^{-1} \sum_{i=1}^{T} \hat{\varepsilon}_{t}(\hat{\beta}) \hat{\varepsilon}_{t}^{\prime}(\hat{\beta})$, where $\hat{\varepsilon}_{t}(\hat{\beta})=\left[\left(\hat{\beta}^{\prime} z_{t-1}\right)^{\prime}, \Delta z_{t-1}^{\prime}\right]^{\prime}$.

Also, $\bar{B}=\beta_{\perp} \beta_{\perp}^{\prime} M^{\prime}+\beta_{\perp} E_{12}\left(I-E_{22}\right)^{-1} L^{\prime} G^{\prime} K^{-1}$, where $\beta_{\perp}$ is a $4 \times 3$ matrix such that $\beta_{\perp}^{\prime} \beta=0, M=\left[\begin{array}{c}I_{4} \\ 0\end{array}\right], E=G^{\prime} D G=\left[\begin{array}{ccc}I_{3} & \beta_{\perp}^{\prime} \alpha & \beta_{\perp}^{\prime} \Gamma_{1} H \\ 0 & 1+\beta^{\prime} \alpha & \beta^{\prime} \Gamma_{1} H\end{array}\right]=\left[\begin{array}{cc}I_{3} & E_{12} \\ 0 & E_{22}\end{array}\right]$, $G=I_{2} \otimes H, D=\left[\begin{array}{cc}I_{4}+\beta^{\prime} \alpha & \Gamma_{1} \\ \alpha \beta^{\prime} & \Gamma_{1}\end{array}\right], H=\left[\beta_{\perp}, \beta\right], L=\left[\begin{array}{c}0 \\ I_{5}\end{array}\right]$ and $K=\left[\begin{array}{cc}I_{4} & 0 \\ I_{4} & -I_{4}\end{array}\right]$.

Further, we define the long-run impact matrix $C=\beta_{\perp}\left(\alpha_{\perp}^{\prime} \Gamma \beta_{\perp}\right)^{-1} \alpha_{\perp}^{\prime}$, where $\alpha_{\perp}$ is a $4 \times 3$ matrix such that $\alpha_{\perp}^{\prime} \alpha=0$ and $\Gamma=-\left(I+\Pi_{2}\right), P=K^{\prime-1} G L\left(I_{5}-E_{22}^{\prime}\right)^{-1}\left[\begin{array}{cc}I & 0 \\ 0 & I \otimes H^{\prime}\end{array}\right]$. Note that $Q^{-g}$ denotes the generalised inverse of matrix $Q$ and $s=\operatorname{rank}\left(R_{L} \beta_{\perp}\right) \times$ $\left\{\operatorname{rank}\left(R_{R}^{*} \beta\right)+1\right\}$.

\section{References}

Abosedra, Salah, and Hamid Baghestani. 1989. New evidence on the causal relationship between United States energy consumption and gross national product. The Journal of Energy and Development 14: 285-92.

Acaravci, Ali. 2010. Structural breaks, electricity consumption and economic growth: Evidence from Turkey. Journal for Economic Forecasting 2: 140-54.

Agovino, Massimiliano, Silvana Bartoletto, and Antonio Garofalo. 2018. Modelling the relationship between energy-intensity and GDP for European countries: An historical perspective (1800-2000). Energy Economics 82: 114-34. [CrossRef]

Aizenman, Joshua, and Nancy P. Marion. 1993. Policy Uncertainty, Persistence and Growth. Review of International Economics 1: 145-63. [CrossRef]

Akarca, Ali T., and Thomas Veach Long. 1980. On the relationship between energy and GNP: A re-examination. Journal of Energy Finance \& Development 5: 326-31.

Ang, James B. 2008. Economic development, pollutant emissions and energy consumption in Malaysia. Journal of Policy Modeling 30: 271-8. [CrossRef]

Apergis, Nicholas, and James E. Payne. 2012. Renewable and non-renewable energy consumption-growth nexus: Evidence from a panel error correction model. Energy Economics 34: 733-38. [CrossRef]

Aqeel, Anjum, and Mohammad Sabihuddin Butt. 2001. The relationship between energy consumption and economic growth in Pakistan. Asia-Pacific Development Journal 8: 101-10.

Bartleet, Matthew, and Rukmani Gounder. 2010. Energy consumption and economic growth in New Zealand: Results of trivariate and multivariate models. Energy Policy 38: 3508-17. [CrossRef]

Batrancea, Larissa. 2021. An Econometric Approach Regarding the Impact of Fiscal Pressure on Equilibrium: Evidence from Electricity, Gas and Oil Companies Listed on the New York Stock Exchange. Mathematics 9: 630. [CrossRef]

Batrancea, Ioan, Larissa Batrancea, Malar Maran Rathnaswamy, Horia Tulai, Gheorghe Fatacean, and Mircea-Iosif Rus. 2020. Greening the Financial System in USA, Canada and Brazil: A Panel Data Analysis. Mathematics 8: 2217. [CrossRef]

Belke, Ansgar, Frauke Dobnik, and Christian Dreger. 2011. Energy Consumption and Economic Growth: New Insights into the Co-integration Relationship. Energy Economics 33: 782-89. [CrossRef]

Bernanke, Ben S. 1983. Irreversibility, Uncertainty, and Cyclical Investment. Quarterly Journal of Economics 98: 85-106. [CrossRef]

Black, Fischer. 1987. Business Cycles and Equilibrium. Cambridge: Blackwell.

Bowden, Nicholas, and James E. Payne. 2009. The causal relationship between U.S. energy consumption and real output: A disaggregated analysis. Journal of Policy Modeling 31: 180-88. [CrossRef] 
Carmona, Mónica, Emilio Congregado, Julia Feria, and Jesús Iglesias. 2017. The energy-growth nexus reconsidered: Persistence and causality. Renewable and Sustainable Energy Reviews 71: 342-47. [CrossRef]

Carrion-i-Silvestre, Josep Lluís, Dukpa Kim, and Pierre Perron. 2009. GLS-based unit root tests with multiple structural breaks under both the null and the alternative hypotheses. Econometric Theory 25: 1754-92. [CrossRef]

Chang, Ching-Chih. 2010. A multivariate causality test of carbon dioxide emissions, energy consumption and economic growth in China. Applied Energy 87: 3533-37. [CrossRef]

Cheng, Benjamin S. 1995. An investigation of cointegration and causality between energy consumption and economic growth. The Journal of Energy and Development 21: 73-84.

Cheng, Benjamin S. 1999. Causality between energy consumption and economic growth in India: An application of cointegration and error-correction modeling. Indian Economic Review 34: 39-49.

Damette, Olivier, and Majda Seghir. 2013. Energy as a driver of growth in oil exporting countries? Energy Economics 37: 193-99. [CrossRef]

Eggoh, Jude C., Chrysost Bangaké, and Christophe Rault. 2011. Energy consumption and economic growth revisited in African countries. Energy Policy, 7408-21. [CrossRef]

Erdal, Gülistan, Hilmi Erdal, and Kemal Esengün. 2008. The causality between energy consumption and economic growth in Turkey. Energy Policy 36: 3838-42. [CrossRef]

Ewing, Bradley T., Ramazan Sari, and Ugur Soytas. 2007. Disaggregate energy consumption and Industrial output in the United States. Energy Policy 35: 1274-81. [CrossRef]

Fallahi, Firouz. 2011. Causal relationship between energy consumption (EC) and GDP: A Markov-switching (MS) causality. Energy 36: 4165-70. [CrossRef]

Fatai, Koli, Les Oxley, and Francis Gordon Scrimgeour. 2004. Modelling the causal relationship between energy consumption and GDP in New Zealand, Australia, India, Indonesia, the Philippines and Thailand. Mathematics and Computers in Simulation 64: 431-45. [CrossRef]

Gately, Dermot, and Hiliard G. Huntington. 2002. The asymmetric effects of changes in price and income on energy and oil demand. The Energy Journal 23: 19-55. [CrossRef]

Hacker, Jacob S., Gregory A. Huber, Austin Nichols, Philipp Rehm, Mark Schlesinger, Rob Valletta, and Stuart Craig. 2014. The Economic Security Index: A New Measure for Research and Policy Analysis. The Review of Income and Wealth 60: S5-S32. [CrossRef]

Hnatkovska, Viktoria, and Norman Loayza. 2005. Volatility and Growth. In Managing Economic Volatility and Crises: A Practitioner's Guide. Edited by Aizenman Joshua and Brian Pinto. Cambridge: Cambridge University Press.

Hossein, Abbasinejad, Gudarzi Farahani Yazdan, and Asghari Ghara Ehsan. 2012. The relationship between energy consumption, energy prices and economic growth: Case study (OPEC countries). OPEC Energy Review 36: 272-86. [CrossRef]

Jalil, Abdul. 2014. Energy-Growth conundrum in energy exporting and importing countries: Evidence from heterogeneous panel methods robust to cross-sectional dependence. Energy Economics 44: 314-24. [CrossRef]

Jamil, Faisal, and Eatzaz Ahmad. 2010. The relationship between electricity consumption, electricity prices and GDP in Pakistan. Energy Policy 38: 6010-25. [CrossRef]

Joyeux, Roselyne, and Ronald D. Ripple. 2011. Energy consumption and real income: A panel cointegration multi-country study. The Energy Journal 32: 107-41. [CrossRef]

Judson, Ruth, and Athanasios Orphanides. 1999. Inflation, volatility and growth. International Finance 1: 117-38. [CrossRef]

Kraft, John, and Arthur Kraft. 1978. On the relationship between energy and GNP. Journal of Energy Development 3: 401-3.

Larissa, Batrancea, Rathnaswamy Malar Maran, Batrancea Ioan, Nichita Anca, Rus Mircea-Iosif, Tulai Horia, Fatacean Gheorghe, Masca Ema Speranta, and Morar Ioan Dan. 2020. Adjusted Net Savings of CEE and Baltic Nations in the Context os Sustainable Economic Growth: A Panel Data Analysis. Journal of Risk and Financial Management 13: 234. [CrossRef]

Liddle, Brantley, and Perry Sadorsky. 2020. How much do asymmetric changes in income and energy prices affect energy demand? The Journal of Economic Asymmetries 21: e00141. [CrossRef]

Liddle, Brantley, Russell Smyth, and Xibin Zhang. 2020. Time-varying income and price elasticities for energy demand: Evidence from a middle-income panel. Energy Economics 86: 104681. [CrossRef]

Medlock, Kenneth, and Ronald Soligo. 2021. Economic Development and End-Use Energy Demand. The Energy Journal 22: 77-105. [CrossRef]

Menegaki, Angeliki N., and Stella Tsani. 2018. Critical Issues to Be Answered in the Energy-Growth Nexus (EGN) Research Field. In The Economics and Econometrics of the Energy-Growth Nexus. Cambridge: Academic Press, pp. 141-84.

Mohammadi, Hassan, and Shahrokh Parvaresh. 2014. Energy consumption and output: Evidence from a panel of 14 oil exporting countries. Energy Economics 41: 41-46. [CrossRef]

Nepal, Rabindra, Tooraj Jamasb, and Clement Allan Tisdell. 2014. Market related reforms and increased energy efficiency in transition countries: Empirical evidence. Applied Economics 46: 4125-36. [CrossRef]

Owyang, Michael T., Jeremy Piger, and Howard J. Wall. 2008. A State-Level Analysis of the Great Moderation. Regional Science and Urban Economics 38: 578-89. [CrossRef]

Paul, Shyamal, and Rabindra N. Bhattacharya. 2004. Causality between energy consumption and economic growth in India: A note on conflicting results. Energy Economics 26: 977-83. [CrossRef] 
Payne, James E. 2009. On the dynamics of energy consumption and output in the US. Applied Energy 86: 575-77. [CrossRef]

Pindyck, Robert S. 1991. Irreversibility, Uncertainty, and Investment. Journal of Economic Literature 29: 1110-48.

Rajaguru, Gulasekaran, and Tilak Abeysinghe. 2008. Temporal aggregation, cointegration and causality inference. Economics Letters 101: 223-26. [CrossRef]

Rajaguru, Gulasekaran, Michael O'Neill, and Tilak Abeysinghe. 2018. Does Systematic Sampling Preserve Granger Causality with an Application to High Frequency Financial Data? Econometrics 6: 31. [CrossRef]

Rashid, Abdul, and Ozge Kandemir Kocaaslan. 2013. Does Energy Consumption Volatility Affect Real GDP Volatility? An Empirical Analysis for the UK. International Journal of Energy Economics and Policy 3: 384-94.

Rühl, Christof, Paul Appleby, Julian Fennema, Alexander Naumov, and Mark Schaffer. 2012. Economic development and the demand for energy: A historical perspective on the next 20 years. Energy Policy 50: 109-16. [CrossRef]

Salim, Ruhul, Shuddhasattwa Rafiq, Sahar Shafiei, and Yao Yao. 2019. Does urbanization increase pollutant emission and energyintensity? Evidence from some Asian developing economies. Applied Economics 51: 4008-24. [CrossRef]

Shahbaz, Muhammad, Muhammad Zeshan, and Talat Afza. 2012. Is energy consumption effective to spur economic growth in Pakistan? New evidence from bounds test to level relationships and Granger causality tests. Economic Modeling 29: 2310-319. [CrossRef]

Shahbaz, Muhammad, Muhammad Zakaria, Syed Jawad Hussain Shahzad, and Mantu Kumar Mahalik. 2018. The energy consumption and economic growth nexus in top ten energy-consuming countries: Fresh evidence from using the quantile-on-quantile approach. Energy Economics 71: 282-301. [CrossRef]

Śmiech, Sławomir, and Monika Papież. 2014. Energy consumption and economic growth in the light of meeting the targets of energy policy in the EU: The bootstrap panel Granger causality approach. Energy Policy 71: 118-29. [CrossRef]

Soytas, Ugur, and Ramazan Sari. 2006. Energy consumption and income in G-7 countries. Journal of Policy Modeling 28: 739-50. [CrossRef]

Soytas, Ugur, Ramazan Sari, and Bradley T. Ewing. 2007. Energy consumption, income, and carbon emissions in the United States. Ecological Economics 62: 482-89. [CrossRef]

Stern, David I. 1993. Energy and economic growth in the USA. A multivariate approach. Energy Economics 15: 137-50. [CrossRef]

Stern, David I. 2000. A multivariate cointegration analysis of the role of energy in the US macroeconomy. Energy Economics 22: 267-83. [CrossRef]

Tang, Chor Foon. 2009. Electricity consumption, income, foreign direct investment, and population in Malaysia: New evidence from multivariate framework analysis. Journal of Economic Studies 4: 371-82. [CrossRef]

Tiba, Sofien, and Anis Omri. 2017. Literature survey on the relationships between energy, environment and economic growth. Renewable and Sustainable Energy Reviews 69: 1129-46. [CrossRef]

Van Benthem, Arthur, and Mattia Romani. 2009. Fuelling growth: What drives energy demand in developing countries? The Energy Journal 30: 91-114. [CrossRef]

Wang, Sisi. S., Dong Q. Zhou, Peng Zhou, and Qunwei Wang. 2011a. $\mathrm{CO}_{2}$ emissions, energy consumption and economic growth in China: A panel data analysis. Energy Policy 39: 4870-75. [CrossRef]

Wang, Yuan, Yichen Wang, Jing Zhou, Xiaodong Zhu, and Genfa Lu. 2011b. Energy consumption and economic growth in China: A multivariate causality test. Energy Policy 39: 4399-406. [CrossRef]

World Development Indicators. 2017. The World Bank Group. Washington: World Bank.

Yamamoto, Taku, and Eiji Kurozumi. 2006. Tests for long-run Granger non-causality in cointegrated systems. Journal of Time Series Analysis 27: 703-23. [CrossRef]

Yildirim, Ertugrul, and Alper Aslan. 2012. Energy consumption and economic growth nexus for 17 highly developed OECD countries: Further evidence based on bootstrap-corrected causality tests. Energy Policy 51: 985-93. [CrossRef]

Yu, Eden S. H., and Been-Kwei Hwang. 1984. The relationship between energy and GNP: Further results. Energy Economics 6: 186-90. [CrossRef]

Yu, Eden S. H., and Jang C. Jin. 1992. Cointegration tests of energy consumption, income, and employment. Resources and Energy 14: 259-66. [CrossRef]

Zhang, Yue-Jun. 2011. Interpreting the dynamic nexus between energy consumption and economic growth: Empirical evidence from Russia. Energy Policy 39: 2265-72. [CrossRef]

Zhixin, Zhang, and Ren Xin. 2011. Causal relationships between energy consumption and economic growth. Energy Procedia 5: $2065-71$. [CrossRef] 